\title{
AUGUSTINO VOLDEMARO VEIKLA UŽSIENIO POLITIKOS SRITYJE STEIGIAMOJO SEIMO LAIKOTARPIU
}

\author{
Dr. Audroné Veilentienė
}

Kauno technologijos universitetas

Kaunas University of Technology

K. Donelaičio g. 73, LT-44029 Kaunas

El.paštas audrone.veilentiene@ktu.lt

\section{Santrauka}

Straipsnyje analizuojama prof. Augustino Voldemaro veikla ir pozicija užsienio politikos srityje Steigiamojo Seimo laikotarpiu. Kol buvo suformuotas Kazio Griniaus Ministru kabinetas, prof. A. Voldemaras laikinai èjo užsienio reikalu ministro pareigas, vèliau buvo Lietuvos atstovas Tautų Sąjungoje, o atsistatydinęs iš šiu pareigu griežtai kritikavo krikščioniu demokratu vykdoma užsienio politiką. Prof. A. Voldemaras daug prisidejo formuojant Lietuvos užsienio politika ir dare nemaža ịtaka, net būdamas opozicijoje, tačiau ši jo veikla iki šiol yra mažai tyrinèta.

Reikšminiai žodžiai: Augustinas Voldemaras; užsienio politika; Tautų Sąjunga; Steigiamasis Seimas.

\section{Ivadas}

Istorikas ir poliglotas prof. Augustinas Voldemaras Lietuvos valstybès atkūrimo pradžioje buvo bene labiausiai išsilavinęs žmogus visoje Lietuvoje. Be to, jis pasižymėjo tvirta valia, kritišku mąstymu, mokejimu polemizuoti, greita reakcija ir pasitikejjimu savimi. Šios 
savybès, matyt, padejo jam tapti pirmuoju Ministru Pirmininku ir užsienio reikalų ministru. A. Voldemaras igavo politinès ir diplomatinès patirties dirbdamas Lietuvos Valstybès Taryboje, Vyriausybeje, Paryžiaus taikos konferencijoje, todèl jo nuomonè užsienio politikos klausimais buvo svarbi ir Steigiamojo Seimo laikotarpiu, nors Tautos pažangos partija pralaimèjo rinkimus ir atsidūrè opozicijoje.

Kai A. Voldemaras buvo pašalintas iš Ministro Pirmininko pareigų 1929 m. rudenị, ir dar po kelių nepavykusių bandymų grąžinti jị i valdžią siekiant galutinai sužlugdyti Prezidento Antano Smetonos priešininką ir sumenkinti jo pasiekimus, A. Voldemaro veikla buvo pradèta vertinti tendencingai. Pavyzdžiui, buvęs užsienio reikalų ministras Juozas Purickis 1933 m. Lietuvos šaulių sąjungos žurnale „Trimitas“ publikuotuose atsiminimuose nutylèjo kai kurias savo klaidas ir stengèsi sumenkinti A. Voldemaro veiklą ginant Lietuvos interesus Tautų Sąjungoje $^{1}$. Sovietų okupacijos metais A. Voldemaras buvo kaltinamas fašizmo įvedimu Lietuvoje, jo veikla vertinama tik neigiamai, o charakterio bruožai karikatūrinami. Šiuolaikinė istoriografija iki šiol neatsikrato autoritarizmo laikotarpiu ir sovietų okupacijos metais suformuotų stereotipų, todèl tikimès, kad šis mokslinis straipsnis prisidès prie minètų stereotipų laužymo ir objektyvaus šio politiko veiklos įvertinimo.

Prof. A. Voldemaro veikla ir požiūris ił užsienio politikos problemas Steigiamojo Seimo laikotarpiu istoriografijoje nèra plačiau nagrinèti. Apie Lietuvos atstovavimą Tautų Sąjungoje monografijose šiek tiek rašė Gintautas Vilkelis² ir Vilma Bukaité3. Jie teigè, kad A. Voldemaras, sutikdamas su plebiscitu, nesilaikẻ užsienio reikalų ministro J. Purickio instrukcijų, tačiau plačiau neanalizavo nei A. Voldemaro motyvų, nei taktikos Tautų Sąjungos Tarybos posèdžiuose.

1 Dr. Juozas Purickis-Vygandas. Iš Vilniaus pagrobimo laikų. Vilniaus klausimas 1918-1922 liudininku akimis. Trakai: Voruta, 2013, p. 45.

2 Vilkelis, G. Lietuvos ir Lenkijos santykiai Tautu Sajungoje. Vilnius: Versus Aureus, 2004.

3 Bukaitè, V. Nepriklausomybès Akto signataras Petras Klimas. Vilnius: Lietuvos nacionalinis muziejus, 2016. 
A. Voldemaro indèlį rengiant Lietuvos ir Sovietų Rusijos taikos sutartị bei veiklą Tautų Sąjungoje padejo ištirti Lietuvos centriniame valstybès archyve (toliau - LCVA) Užsienio reikalų ministerijos fonde (f. 383) ir Lietuvos mokslo akademijos Vrublevskių bibliotekos Rankraščių skyriaus (LMAB RS) A. Voldemaro fonde (f. 172) esantys dokumentai $^{4}$, Steigiamojo Seimo stenogramos ${ }^{5}$, A. Voldemaro raštai ${ }^{6}$, Petro Klimo ${ }^{7}$ ir Juozo Purickio atsiminimai ${ }^{8}, 1920-1921$ m. periodinė spauda. Tyrimui ypač buvo naudingi A. Voldemaro raštuose publikuoti iš prancūzų kalbos išversti jo pranešimai Tautų Sąjungoje, 1920 m. jie buvo išspausdinti Paryžiuje ir Berlyne atskirais leidiniais ir platinami užsienio valstybių politikams bei diplomatams ${ }^{9}$. A. Voldemaro požiūrị i č šio laikotarpio užsienio politiką - sutarties su Sovietų Rusiją pasirašymą, santykius su Lenkija, Klaipedos klausimą ir Hymanso projektus atskleisti padejo 1920-1922 m. Tautos pažangos partijos periodinè spauda.

Straipsnio tikslas - išanalizuoti prof. A. Voldemaro veiklą užsienio politikos srityje ir jo požiūrị i u užsienio politiką Steigiamojo Seimo laikotarpiu.

Chronologinès ribos - 1920 m. gegužès 15 d. - 1922 m. lapkričio 13 diena.

Tyrimo metodai: aprašomasis, analizès ir lyginamasis.

4 LCVA, f. 383, ap. 7, b. 90, 92; LMAB RS, f. 172, b.

Steigiamojo Seimo darbai. Kaunas, 1920-1922.

6 Profesorius Augustinas Voldemaras. Raštai. 90 metu sukakčiai paminèti. Čikaga: Laisvosios Lietuvos knygų leidykla, 1976.

7 Klimas, P. Iš mano atsiminimu. Vilnius: Lietuvos enciklopedijų redakcija, 1990.

8 Dr. Juozas Purickis-Vygandas. Iš Vilniaus pagrobimo laikų. Vilniaus klausimas 1918-1922 liudininku akimis. Trakai, 2013.

9 Profesorius A. Voldemaras. Lietuva ir Lenkija [Professeur A. Voldemar, Ministre Des Affaires Etrangeres De Lithuanie. Lithuanie Et Pologne. Berlin: Elsnerdruck, 1920]; Profesorius A. Voldemaras. Rusų-Lenkų-Lietuvių santykiai [Relations Russo-Polono-Lithuaniennes. Par le Professeur A. Voldemar. Paris, 1920]. Profesorius Augustinas Voldemaras. Raštai, p. 195-257. 


\section{Laikinasis užsienio reikalų ministras}

Susirinkus Steigiamajam Seimui prof. A. Voldemaras iki 1920 m. birželio 19 d., kol buvo sudaryta nauja Vyriausybė, èjo užsienio reikalų ministro pareigas. Svarbiausi Steigiamojo Seimo uždaviniai užsienio politikos srityje buvo nustatyti valstybès sienas ir gauti tarptautinị pripažinimą. Tuo metu Lietuva buvo pripažinta tik Vokietijos, šalia vyko grèsmę nepriklausomybei keliantis Lenkijos ir Sovietų Rusijos karas. Prof. A. Voldemaras buvo vertinamas dèl išsilavinimo ir diplomatinès patirties, todèl netrukus jis gavo Ministro Pirmininko Kazio Griniaus pasiūlymą dirbti jo vadovaujamame Ministrų kabinete. I ši siūlymą birželio 16 d. prof. A. Voldemaras atsakẻ laišku, kurị liepos 2 d. publikavo Tautos pažangos partijos laikraštyje "Tauta"10. Laiške jis išdèstè sąlygas, kurias išpildžius jis būtų galèjęs dirbti Ministrų kabinete. Pirmiausia A. Voldemaras pareikalavo pataisyti Laikinosios Konstitucijos 16-ąji paragrafą, kuris garantavo streikų laisvę ir mirties bausmès panaikinimą. Jo nuomone, tai valstybę gali atvesti prie suirutès ir netgi pražudyti. Taip pat jis atkreipè dėmesị, kad Konstitucijoje nerašoma, kas yra vyriausiasis kariuomenès vadas, o tai gali dezorganizuoti kariuomenę ir ịtraukti ją í politikos sūkurius. Prof. A. Voldemaras pareikalavo, kad Konstitucijoje būtų ịrašyta anksčiau galiojusi nuostata, kad vyriausiasis kariuomenès vadas yra Prezidentas. Taip pat jis siūlè grąžinti Prezidentui veto teisę, kad nebūtų priimta neapgalvotų ịstatymų, kurie galètų dezorganizuoti valstybès ekonominị ir socialinị gyvenimą. Ketvirtąja sąlyga A. Voldemaras įrašè kabineto narių kompetenciją toje srityje, kuriai jie vadovaus, penktąja - garantiją, kad Seimas, kontroliuodamas valdžią, nesikiš ị Vyriausybės darbą. Suprantama, kad Ministras Pirmininkas K. Grinius negalèjo išpildyti prof. A. Voldemaro reikalavimų, nes Laikinąją Konstituciją priemė Steigiamasis Seimas. Akivaizdu, kad nesutapo rinkimus laimejjusių krikščionių demokratų ir liaudinin-

${ }_{10}$ Tautos Pažangos dienynas. Tautos Pažangos sąlygos dalyvavimo Ministerių kabinete, Ministeriui Pirmininkui dr. Griniui pasiūlius. Tauta. 192007 02, Nr. 26, p. 3. 
kų bei Tautos pažangos partijos požiūris ị demokratiją ir Prezidento instituciją.

Tautos pažangos partijos lyderiai, likę opozicijoje, atidžiai sekè Steigiamojo Seimo darbus ir negailejo kritikos. A. Voldemaras sukritikavo ir pirmąji Steigiamojo Seimo žingsnị - rezoliuciją, kuri skelbè: „Lietuvos Steigiamasis Seimas, reikšdamas Lietuvos žmonių valią, proklamuoja esant atstatytą nepriklausomą Lietuvos valstybę, kaipo demokratinę respubliką, etnologinèm sienom ir laisvą nuo visų valstybinių ryšių, kurie yra buvę su kitom valstybėm."11

A. Voldemaras rašè, kad Taryba ir Laikinoji Vyriausybè tiek stengèsi, kad tie ryšiai būtų užmegzti, o Seimas ima ir panaikina juos ${ }^{12}$. A. Voldemaras suprato, kad Seimas taip negalvojo ir norejo pasauliui dar kartą paskelbti apie Lietuvos nepriklausomybę, bet, jo manymu, Seimas nemokejo tiksliai formuluoti savo ketinimų. A. Voldemaro teigimu, ši rezoliucija duos daugiau negatyvių rezultatų negu pozityvių. Jis nurodé, kad Lenkija nė karto Seimo nutarimu neskelbė savo nepriklausomybès, tačiau niekas neabejoja, kad ji yra nepriklausoma. A. Voldemaras nurodé, kad kartą jau buvo paskelbta Lietuvos nepriklausomybè, todèl antrą kartą to daryti nereikèjo. Be to, jo nuomone, ši rezoliucija iki balsavimo buvo laikoma kaip didžiausia paslaptis, nes apie ją nežinojo ne tik visuomené, bet ir tuo laiku už Lietuvos politiką atsakingi žmonès. Iš šių teiginių galima spręsti, kad užsienio reikalų ministras A. Voldemaras nežinojo apie Steigiamajame Seime planuojamą priimti rezoliuciją.

Vis dèlto reikia pripažinti, kad A. Voldemaras pernelyg kritiškai vertino šią Steigiamojo Seimo rezoliuciją ir neižziūrèjo jos reikšmės. Teisès istorikas Mindaugas Maksimaitis nurode teisinius Vasario 16-osios nepriklausomybès akto ir Steigiamojo Seimo rezoliucijos skirtumus: 1) Vasario 16-osios akte Lietuvos Taryba skelbè, kad ji atstovauja lietuvių tautai, o Lietuvos Steigiamojo Seimo rezoliucijo-

1119200515 I sesijos 1 posèdis. Steigiamojo Seimo darbai, Kaunas, 1920-1922.

12 Voldemaras, A. Pirmieji žingsniai. Tauta. 192007 09, Nr. 28, p. 2-3. 
je buvo išreikšta Lietuvos žmonių, t. y. visų Lietuvos piliečių, valia; 2) Lietuvos Taryba paskelbè apie valstybès atkūrimą, o Steigiamasis Seimas konstatavo, kad valstybè jau atkurta, ir nustatė konkrečią atkurtos valstybès valdymo formą - demokratinę respubliką ${ }^{13}$. Ypatingą gegužès $15 \mathrm{~d}$. rezoliucijos reikšmę išeivijoje atskleidè teisininkas Liudas Šmulkštys. Jis tvirtino, kad net jei Steigiamasis Seimas, prièmęs šią rezoliuciją, dèl kokių nors priežasčių būtų išsiskirstęs, vis dèlto jis būtų ịvykdęs abu Vasario 16-osios aktu jam pavestus uždavinius - nustatęs Lietuvos valstybės pagrindus (paskelbęs, kad Lietuva yra demokratinè respublika) ir santykius su kitomis valstybėmis (nutraukęs visus buvusius valstybinius ryšius su kitomis šalimis) ${ }^{14}$. Nors konkrečios valstybès rezoliucijoje neįvardijamos, tačiau aišku, kad čia kalbama apie ryšius ne tik su okupantemis Vokietija ir Rusija, bet taip pat ir apie ryšius su Lenkija, su kuria kadaise Lietuvą siejo bendros valstybès istorija.

Steigiamojo Seimo nariai kaltino A. Voldemarą, kad jis, eidamas užsienio reikalų ministro pareigas, delsè pradèti derybas su Maskva. Krikščionių demokratų lyderio Mykolo Krupavičiaus teigimu, Lietuvos krikščionių demokratų partijos (toliau - LKDP) centro komiteto igaliotas atstovas $1920 \mathrm{~m}$. vasario $17 \mathrm{~d}$. Ministrų kabinete bandè priversti Vyriausybę „daryt žingsnių taikai su bolševikais“15. Šiai misijai nepavykus, LKDP centro komitetas $1920 \mathrm{~m}$. kovo $16 \mathrm{~d}$. nusprendè Valstybès Taryboje imtis griežčiausių priemonių ir priversti Laikinąją Vyriausybę pradèti derybas su Sovietų Rusija. Netrukus krikščionių demokratų atstovai Valstybès Taryboje kunigas Juozas Vailokaitis ir Aleksandras Stulginskis griežtai pareikalavo iš A. Voldemaro, kad būtų pradètos derybos su bolševikais. LKDP centro komitete buvo

${ }^{13}$ Maksimaitis, M. Apie Steigiamojo Seimo konstitucinès kūrybos pritaikymą išsivaduosiančiai Lietuvai: išeivijos požiūris (1945-1990). Jurisprudencija. 2010, Nr. 4 (122), p. 11-12.

14 Šmulkštys, L. Žvilgsnis ị Steigiamojo Seimo istoriją. Sëja.1960, Nr. 2 (64), p. 8.

1519200915 I sesijos 41 posèdis. Steigiamojo Seimo darbai. Kaunas, 1920-1922. 
nutarta, jei A. Voldemaras nesutiks, pareikšti jam nepasitikejjimą. Lietuvos socialistų liaudininkų demokratų partijos (toliau - LSLDP) lyderis Mykolas Sleževičius taip pat manė, kad derybas su Sovietų Rusija reikejo pradèti 1919 m. spalio mėnesí, kai anglų atstovas Rygoje pasakè, kad tam neprieštarauja. Jis kaltino Tautos pažangos partiją ir krikščionis demokratus, kad tuo metu derybos neįvyko ${ }^{16}$.

Gegužès 30 d. ị Kauną pasitarti su Vyriausybe grịžo Lietuvos delegacijos dalis, kuri nuo gegužès $1 \mathrm{~d}$. buvo išvykusi derètis dèl taikos $\mathfrak{i}$ Maskvą. Lietuvos ir Sovietų Rusijos derybų metu vyko Lenkijos pradètas permainingas karas su Sovietų Rusija. Iš pradžių sekèsi Lenkijai, jos kariuomenė gegužès 7 d. užėmė Kijevą, tačiau netrukus sovietai pradèjo stumti Lenkijos kariuomenę. Tuo metu Sovietų Rusijos derybininkai pasiūlè Lietuvos delegacijai sudaryti karinę sutartị, nukreiptą prieš Lenkiją. Lietuvos delegacija norejo nusileisti Rusijai, tačiau Lietuvos Vyriausybẻ buvo priešingos nuomonès, todèl atšaukè Lietuvos delegacijos pirmininką Tomą Naruševičių ir kelis jos narius ị Kauną pasikonsultuoti. Nuo gegužès 30 d. iki birželio 13 d. įvyko šeši Užsienio reikalų komisijos, Vyriausybės atstovų ir delegacijos narių posėdžiai, kuriuose dalyvavo ir užsienio reikalų ministras A. Voldemaras. Komisija svarstė instrukcijos, skirtos Lietuvos delegacijai, projektą.

Birželio 5 d. Užsienio reikalų komisijos posėdyje daugiausia diskusijų sukèlè 2-asis instrukcijos punktas, kuris numatè, „jeigu rusai užimtų iš apibrèžtos teritorijos dalis lenkų okupuotas, jie pasižada tuoj atiduoti jas Lietuvos valdžiai“"17. Delegacijos pirmininkas T. Naruševičius norejjo, kad instrukcija būtų platesnè ir labiau konkretizuota. Delegacijos narys Simonas Rozenbaumas bijojo, kad bolševikai nepasiūlytų lietuviams patiems užimti tuos plotus. Seimo Žydų frakcijos narys Ozeras Finkelšteinas taip pat nuogąstavo, kad 2-ojo punk-

1619200915 I sesijos 41 posėdis. Steigiamojo Seimo darbai. Kaunas, 1920-1922.

1719200605 Užsienio reikalų komisijos posėdžio protokolas. LCVA, f. 383, ap. 7,

b. $77,1.151-152$. 
to taikymas gali įvelti Lietuvą i karą, nes, jo manymu, 3-iasis punktas taip pat turi „karingą atspalvị“. Jis siūlè 3-iąji punktą visai išmesti, o 2-ąji modifikuoti taip, kad Lietuva pasiliktų „laisvas rankas“ spręsti, ar jai užimti lenkų kariuomenės paliktas lietuvių žemes, ar neužimti.

A. Voldemaras kritikavo žydų atstovus, aiškindamas, kad, jei lietuviai sèdès rankas sudèję ir nieko nedarys dèl savo žemių išvadavimo, tai naivu būtų tikètis, kad bolševikai jas atiduos kaip dovaną. Jis stebejosi, kad tokius pasiūlymus daro S. Rozenbaumas ir O. Finkelšteinas, abu jie nori ne tik etnografinès Lietuvos, bet ir Balstogès, Gardino gubernijos ir kt. A. Voldemaro teigimu, instrukcija kaip tik nenurodo būtinybės kariauti su viena ar kita puse, bet suteikia galimybę pasilikti „laisvas rankas“ elgtis pagal aplinkybes.

Toliau svarstytas 3-iasis punktas taip pat sukèlè nemažai diskusijų: „3. Lietuvos valdžia imsis visų jos galioj esančių priemonių, kad prašalinus jos teritorijoj besančią lenkų kariuomenę. “18

S. Rozenbaumas manè, kad tokia formuluotè reiškia karą, todèl siūlè ji papildyti pataisa: „tatai mes padarysim tuo momentu, kada tai skaitysim reikalinga“. O. Finkelšteinas vèl buvo prieš ši punktą, stebėdamasis, kodèl Lietuva pati dalija bolševikams tokius pažadus. A. Voldemaras aiškino, kad formuluotè yra pakankamai lanksti ir visai nereiškia karo, nors tokios galimybès neatmetė. J. Purickis prieštaravo O. Finkelšteinui ir tvirtino, kad reikalaujant ko nors iš bolševikų reikia jiems ką nors ir pažadèti. Jis neabejojo, kad tokių pažadų bolševikai reikalaus. Vykstant balsavimui dèl O. Finkelšteino pasiūlymo išbraukti ši punktą, visi balsavo prieš, išskyrus ji patį.

Liaudininkų atstovas M. Sleževičius pasiūlè pataisą, kuria būtų išaiškinama šio punkto formuluote, kuri reiškè, kad Lietuva imsis visų jos galioje esančių priemonių, „neišskyrus ir panaudojimo karo pajègos, bet pasirinkimas įrankių, kuriais manoma lenkus pašalinti iš Lietuvos, o taipgi pasirinkimas momento panaudojimui karo pajègos

1819200605 Užsienio reikalų komisijos posèdžio protokolas. LCVA, f. 383, ap. 7, b. 77, 1. 152. 
priklauso išimtinai Lietuvos valdžiai“. Ši pataisa buvo priimta visais balsais, išskyrus O. Finkelšteino. T. Naruševičiaus nuomone, ši pataisa galèjo būti ịrašyta tik slaptoje sutartyje. J. Purickis tikino, kad visas punktas gali būti tik slaptos sutarties objektas. Visais balsais, išskyrus O. Finkelšteino, nutarta, kad visas punktas būtų ịtrauktas ị slaptą protokolą ir viešai neskelbiamas.

Užsienio reikalų ministras A. Voldemaras tvirtino, kad siekdama atgauti savo teritorijas Lietuva negali atsisakyti karo, jeigu tai bus reikalinga, tačiau tai turi nuspręsti ji pati. Jam pritarè socialdemokratų atstovas Vincas Čepinskis, liaudininkų lyderis M. Sleževičius ir krikščionis demokratas J. Purickis, tačiau pastarasis abejojo, ar rusams užteks tokių Lietuvos nuolaidų. T. Naruševičius prieštaravo, kad ị sutartị būtų ịrašytas neutraliteto paskelbimas, jo teigimu, tai apsunkins derybas. Instrukcijos tikslas buvo neleisti Sovietų Rusijai įtraukti Lietuvą i karinị konfliktą, tačiau instrukcijos 2-asis punktas numaté, kad Sovietų Rusijos kariuomenė gali užimti Lenkijos kariuomenès paliktas Lietuvos teritorijas, o 3-iuoju punktu Lietuva pati nutarẻ pasirašyti slaptą susitarimą, kuriame įsipareigojo pašalinti išvaduotoje Lietuvos teritorijoje likusias Lenkijos kariuomenès dalis.

Liepos $12 \mathrm{~d}$. Lietuvos delegacija pasirašè Taikos sutartị su Sovietų Rusija ir kartu slaptą priedą. Kariaujant su Lenkija Sovietų Rusijos kariuomenei reikejjo pereiti per teritoriją, ị kurią pretendavo Lietuva, bet kurią tuo metu buvo užemusi Lenkijos kariuomenè, todèl Rusija privertẻ Lietuvos delegaciją pasirašyti slaptą pareiškimą prie 2-ojo sutarties straipsnio. Jame buvo parašyta, kad vykstant Rusijos ir Lenkijos karui ir Lenkijai okupavus dalį Lietuvos teritorijos „Raudonosios Armijos peržengimo per Lietuvos sieną ir jos dalies teritorijos užèmimo faktas nebus laikomas Taikos sutarties pažeidimu ir nedraugišku aktu Lietuvos atžvilgiu su sąlyga, kad praejjus karinei-strateginei būtinybei Raudonoji Armija bus išvesta iš šios teritorijos. " ${ }^{19}$ Lietuvos delegacijos

19 Svarbiausios Lietuvos Respublikos tarptautinès sutartys 1918-1995. Vilnius, 1997, p. 17. 
pasirašytas slaptasis priedas turèjo apsaugoti Lietuvą, kad ji nebūtų itraukta i Lenkijos ir Sovietų Rusijos karą, ir buvo mažiau pavojingas už instrukcijos numatytą j̇sipareigojimą pačiai Lietuvai pašalinti išvaduotoje teritorijoje likusias Lenkijos kariuomenès dalis.

Pirmąji Steigiamojo Seimo darbo mėnesi prof. A. Voldemaras laikinai èjo užsienio reikalų ministro pareigas, tačiau, laikydamasis Tautos pažangos partijos nutarimo, atsisakè toliau dirbti K. Griniaus Ministrų kabinete. Tautos pažangos partija iškèlè sąlygas keisti Konstitucijos nuostatas, kurios buvo nepriimtinos Steigiamojo Seimo daugumai. A. Voldemaras sukritikavo jau pirmąji Steigiamojo Seimo priimtą dokumentą - rezoliuciją dèl valstybės nepriklausomybės, jos valdymo formos, sienų ir santykių su kitomis valstybėmis, ir tai rodè, kad jis stebės kiekvieną Seimo žingsnị, ypač užsienio politikos srityje. Vis dèlto jis aktyviai dalyvavo rengiant instrukciją Lietuvos delegacijai Maskvoje ir buvo už slaptąji sutarties priedą bei Lietuvos interesų gynimą net ir karinèmis priemonèmis.

\section{Požiūris ị kaimyninių šalių užsienio politiką ir Lietuvos in-} teresus

A. Voldemaras aktyviai reiškèsi Tautos pažangos partijos spaudoje: jis pateikè savo įžvalgas apie užsienio politiką, perspejo apie gresiančius pavojus ir dosniai dalino patarimus Steigiamajam Seimui bei Vyriausybei. Dar nežinodamas apie Taikos sutarties su Sovietų Rusija pasirašymą, A. Voldemaras parašė straipsnị, kuriame perspejo apie grobikišką Sovietų Rusijos politiką ir Lietuvai gresiantị sovietų okupacijos pavojų ${ }^{20}$. Straipsnyje A. Voldemaras aiškino, kad rusai tyčia vilkina derybas su Lietuva, nes jiems sekasi kare su Lenkija, ir nèra jokių garantijų, kad, užèmę Vilnių, jie gera valia atiduos jị Lietuvai. Jis pacitavo Sovietų Rusijos delegacijos pirmininko Adolfo Jofès žodžius, pasakytus T. Naruševičiui, „jei bolševikai paimsią Vilnių, tai

${ }^{20}$ Voldemaras, A. Caveant Consules (Tebudi konsulai (lot.)). Tauta. 192007 14, Nr. 29, 1. 1. 
visai kitaip statysią Vilniaus klausimą “21, ir patarè nebijoti, tačiau būti viskam pasiruošus.

A. Voldemaras buvo teisus, nes sovietai sutartị su Lietuva pasirašè siekdami pagerinti savo karinę padètị ir norèdami apsaugoti Lenkiją puolančios Raudonosios armijos dešinijji sparną, jie tikejjosi priversti Lietuvą kariauti su Lenkija. Raudonosios armijos sẻkmè kare su Lenkijos kariuomene galejjo lemti liepos $12 \mathrm{~d}$. sutarties sulaužymą ir Lietuvos okupaciją, nes liepos pabaigoje sovietų politiniai ir kariniai vadovai Levas Trockis su Michailu Tuchačevskiu buvo parengę Lietuvos užėmimo planą, ji igyvendinti turèjo apie 15 tūkstančių karių ${ }^{22}$. Pralaimèjimas prie Varšuvos privertẻ Sovietų Rusiją keisti planus.

Liepos 16 d. straipsnyje „Taika“ prof. A. Voldemaras nurodè, kad, pasirašiusi Taikos sutartị, Lietuva išvengè didelio pavojaus, tačiau abejojo, ar rusai jos laikysis ir kiek laikysis ${ }^{23}$. Jo nuomone, Lietuvai yra naudinga, kad rusai pasirašè sutartị, kai jiems sekèsi kare, ir tai jie padarè ne priversti, o savo noru, todèl nieko negalès kaltinti, kad jiems taika su Lietuva primesta per prievartą. Jis siūlè Lietuvai labai atsargiai elgtis, kad Sovietų Rusija neapkaltintų jos sutarties sulaužymu. A. Voldemaras numatė, kad gali įvykti susidūrimų su Sovietų Rusijos kariuomene, kai Lietuvos kariuomenè norès užimti jai pagal sutartị atitekusias teritorijas. Jis mane், kad Lenkijos imperializmui karas bus „apdaužęs ragus“, todèl, atsisakius Vilniaus, jai nebus sunku pripažinti ir nepriklausomą Lietuvą su Maskvos sutarties sienomis.

Kitame straipsnyje „Vilniun beeinant“ A. Voldemaras aiškino, kad, nepavykus susitarti su lenkais dèl Vilniaus atidavimo, reikejo jiems ịteikti ultimatumą ir tik tada žygiuoti kariuomenei, nes, ịvykus

21 Voldemaras, A. Caveant Consules (Tebudi konsulai (lot.)). Tauta. 192007 14, Nr. 29, 1. 1.

22 Butkus, Z. Pirmasis Sovietų pasiuntinys Lietuvoje A. Akselrodas: diplomatinès veiklos pusmetis (1920 m. rugsẻjis - $1921 \mathrm{~m}$. kovas). Lietuvos istorijos metraštis. 1996, p. 123.

${ }^{23}$ Voldemaras, A. Taika. Tauta. 192007 16, Nr. 30, 1. 1. 
ginkluotam susirèmimui, buvo apkaltinta Lietuva ${ }^{24}$. Jo nuomone, nereikejjo lenktyniauti su Sovietų Rusijos kariuomene, kurie pirmi užims Vilnių, nes ir taip buvo aišku, kad viena Lietuvos kariuomenè to nebūtų galëjusi padaryti. A. Voldemaras rašè, kad eiti ị Vilnių reikèjo tik gerai pasiruošus - šalia kelių pulkų, kartu turejjo vykti ir jau suformuotas valdžios aparatas. Jis neslèpé, kad apie puse Vilniaus gyventojų bijo ir nenori lietuvių atejjimo, todèl ị Vilnių reikia eiti ne tik „su gerumu, bet ir su drausme“, o drausmé galima tada, jei lietuviai bus visateisiai miesto šeimininkai. Jis neabejojo, kad lietuviai gali sulaukti net ginkluoto vietinių lenkų pasipriešinimo. A. Voldemaras taip pat perspejjo, kad sovietų šeimininkavimas Vilniuje gali labai pakenkti Lietuvos autoritetui, todèl siūlè Lietuvos valdžiai susitarti su sovietų karo vadovybe dèl Vilniaus valdymo arba visiškai pasitraukti iš miesto. Jo nuomone, pirmiausia reikia užtikrinti susisiekimą su Vilniumi telefonu ir geležinkeliu, todèl šie turi būti apsaugoti, taip pat reikès kariuomenès išvaduotoms teritorijoms perimti. Be to, Vilniui reikès maisto, kuro ir elektros, finansinè miesto padètis irgi bus apgailètina, kils problemų ir dèl lenkų savivaldos. Jis apdairiai siūlè iš karto, rimtai neapgalvojus neskirti savo žmonių, bet iš pradžių susipažinti su sąlygomis. Buvęs premjeras atkreipe demesị ị svarbias problemas, kurios kyla Lietuvos Vyriausybei dèl Vilniaus.

A. Voldemaras ne tik duodavo patarimų Vyriausybei, bet ir pats kalbejosi su sovietų kariuomenès vadovybe dèl jos kariuomenès evakuacijos iš Vilniaus. Atsakydamas ị Lenkijos užsienio reikalų ministro rugsejo 5 d. notą Tautų Sąjungai, jis rašè, kad 1920 m. liepos 25 d. jis kalbejo su sovietų komisaru apie padètị Vilniuje ${ }^{25}$. Sovietų komisaras jam pareiškė gavęs ịsakymą iš Maskvos, kad kariuomenei maisto tiekimas galimas tik iš okupuotos teritorijos. Sovietų komisaras su-

${ }^{24}$ Voldemaras, A. Vilniun beeinant. Tauta. 192007 23, Nr. 32, 1. 1.

2519200916 Lietuvos atstovo Tautų Sajungoje A. Voldemaro nota Tautų Sajungos generaliniam sekretoriui E. Drummondui. Voldemaras, A. Rusų-Lenkų-Lietuvių santykiai. Profesorius Augustinas Voldemaras. Raštai, p. 235. 
prato, kad tai pražūtinga okupuotai teritorijai, ir pažadejjo atlyginti gyventojams padarytus nuostolius. Po šio susitikimo prasidejo sovietų karinès vadovybės ir lietuvių delegacijos derybos. Jų pasekmè rugpjūčio $6 \mathrm{~d}$. pasirašyta sutartis dèl sovietų kariuomenès evakuacijos iš okupuotos Lietuvos teritorijos.

Rugpjūčio 6 d. straipsnyje A. Voldemaras pabrèžè, kad Lietuva turi tris didelius kaimynes Vokietiją, Lenkiją ir Rusiją, besikèsinančias pavergti Lietuvą ${ }^{26}$. Jis kaltino Sovietų Rusiją nelojalumu Lietuvai, kadangi ji, vykdydama propagandą, siekè prisijungti Lietuvą. Vesdama derybas su Vakarų Europos valstybėmis Sovietų Rusija negalejo atvirai okupuoti Lietuvos, tačiau ji darè viską, kad Lietuva pati „sugrị̌zuc “ jų darbus ir tikruosius kèslus. A. Voldemaras perspejjo, kad Vilniaus krašte, valdomame sovietų, netrukus kils badas, todèl kvietė Vyriausybę ir Seimą elgtis griežčiau ir atmesti sovietų pasiūlymą sudaryti mišrią komisiją, skirtą Vilniaus perdavimo reikalams. Jis sakè, kad delsimas ratifikuoti sutartị Lietuvai yra labai pavojingas, ir ragino Seimą kuo greičiau tai padaryti.

Sutarties su Sovietų Rusija temą A. Voldemaras taip pat analizavo ir rugpjūčio $10 \mathrm{~d}$. straipsnyje $\mathrm{e}^{27}$. Jis rašè, kad revoliucinių komitetų kūrimas ir raginimas ginklu nuversti „baltagvardiečių“ Kauno valdžią, Sovietų Rusijos skleidžiamas Vilniuje ir kitose sovietų kariuomenès užimtose žemėse, faktiškai pažeidè Taikos sutartị, tačiau kol sutartis buvo neratifikuota, tol nebuvo juridinio pagrindo reikalauti jos laikytis. Rugpjūčio 6 d. Lietuvos Steigiamasis Seimas sutartị ratifikavo, todèl Sovietų Rusija, A. Voldemaro nuomone, bus priversta jos laikytis. Jis rašè, kad lietuviai Vilniuje laukiami kaip išvaduotojai, todèl negalima pridaryti klaidų ir nuvilti gyventojų. Reikia kuo greičiau išvaduotoms teritorijoms sudaryti valdymo aparatą, o, kadangi

${ }^{26}$ Voldemaras, A. Hannibal ante portas [Hanibalas prie vartų]. Tauta. 192008 06, Nr. 35, 1. 1

27 Voldemaras, A. Užimtosios Lietuvos atliuosavimas. Tauta. 192008 10, Nr. 37, p. 1. 
valdininkų trūksta, leisti jiems eiti kelias pareigas. Jis primygtinai ragino valdžią atsižvelgti i šias problemas, nes, jei išvaduotose teritorijose nebus greitai sudaryta Lietuvos valdžia, vietiniai gyventojai pasiges svetimos valdžios, nesvarbu, ar tai būtų lenkų, ar bolševikų.

Rugpjūčio $31 \mathrm{~d}$. ì Lietuvą dirbti atvyko Sovietų Rusijos atstovas Aleksandras Akselrodas su 13 žmonių komanda. A. Voldemaras atkreipè dèmesị i tai, kad Sovietų Rusija, dar neratifikavusi sutarties, atsiunčia atstovą. Jo manymu, sovietai neskuba jos ratifikuoti, nes nori sutarti pakeisti, jei jų padètis pagerètų ar pablogètų. Pirmuoju atveju sovietai stengtųsi apkarpyti Lietuvos teises arba net padaryti „Tarybų Lietuvą“, kuri „savo noru“ prisijungtų prie Sovietų Rusijos ${ }^{28}$. A. Voldemaras rašè, kad Lietuvai būtinai reikia sutartị ratifikuoti anksčiau, negu sutartị su Sovietų Rusija pasirašys Lenkija. Lietuvai reikia, kad Rusija pripažintų jai anksčiau Lenkijos užimtas teritorijas, nes tada ji negalès jų pripažinti Lenkijai, tačiau būtina, kad sutartị ratifikuotų abi šalys. A. Voldemaras manè, kad Lietuvos delegacija padarè didelę klaidą í sutartị neịrašiusi termino, per kiek laiko sutartis turi būti ratifikuota. Taip pat jis abejojo, ar ir Vyriausybè nebus padariusi klaidos, kad priemė Sovietų Rusijos atstovą, kol sutartis neratifikuota. Jis aiškino, kad, gavusi Georgijaus Čičerino pasiūlymą priimti Rusijos atstovybę, Lietuvos Vyriausybė turèjo griežtai atsisakyti tai padaryti, kol sutartis nebus ratifikuota. Neigiamas Lietuvos atsakymas būtų paskatinęs Rusiją greičiau ratifikuoti sutartị, nes sovietai nenori pasauliui atskleisti savo slaptų planų. A. Voldemaro nuomone, sovietai yra mažiau patikimi negu carinès Rusijos diplomatai, be to, jie yra gerokai už juos gudresni, todèl išnaudos kiekvieną neatsargų lietuvių žingsnị. Jis padarè išvadą, kad sovietų pasiuntinybè atsivežè tiek daug žmonių, nes, prisidengdama neliečiamybe, nori dirbti propagandinị darbą.

1920 m. rugpjūčio 17 d. A. Voldemaras Vyriausybei siūlè nepamiršti Klaipèdos reikalų ir griežtai reaguoti ị komisaro Jeano Gabrielio

28 Voldemaras, A. Mūsų santykiai su Rusija. Tauta. 192009 03, Nr. 44, p. 1. 
Petisne pareiškimą, kad negali būti nẻ kalbos apie Klaipėdos prijungimą prie Vokietijos ar Lietuvos. Jis priminè, kad 1919 m. liepą didžiosios valstybės iškilmingai paskelbè, jog Klaipėdos kraštas yra nuo seno lietuvių gyvenama teritorija, o Klaipèda - vienintelis Lietuvos uostas, todèl buvo pažadèta, kai tik paaiškès Lietuvos juridinė padètis, Klaipèdos kraštą atiduoti Lietuvai ${ }^{29}$. J. G. Petisne pareiškimas rodo, kad didžiosios valstybès keičia savo politiką Lietuvos atžvilgiu ir atsiima savo pažadus. A. Voldemaras nurodè, kad $1920 \mathrm{~m}$. liepos $15 \mathrm{~d}$. Briuselyje turèjo būti ekonominiams klausimams skirta konferencija, i kurią buvo deleguotas finansų ministras Ernestas Galvanauskas. I konferenciją jis vyko per Klaipedą. Čia sužinojęs apie konferencijos datos nukèlimą kartu su J. G. Petisne nuvyko ị Paryžių tartis dèl Lietuvos ir Klaipėdos muitų unijos. A. Voldemaras stebejosi, kodèl užsienio politikos klausimus pavesta spręsti finansų ministrui ir kodèl apie tokị svarbų klausimą nieko nežino visuomenè. Grįžęs iš šių pasitarimų J. G. Petisne padarè pareiškimą, kad Klaipèda nebuvo perduota Lietuvai, todèl neaišku, ar tai nèra derybų pasekmè. A. Voldemaras rašè, kad valdžia privalo reaguoti, o visuomené privalo žinoti.

Pasitraukęs iš užsienio reikalų ministro posto A. Voldemaras publicistiniuose straipsniuose patarinejo, kaip turètų elgtis Lietuvos Vyriausybė Sovietų Rusijai kariaujant su Lenkija, perspejo nepasitikèti Rusija, aiškino, ką daryti atgavus Vilnių, kvietė nepamiršti Klaipėdos reikalų.

\section{Kas kaltas dèl siūlymo surengti plebiscitą prièmimo}

A. Voldemaras amžininkų buvo kaltinamas tuo, kad būdamas Lietuvos atstovas Tautų Sąjungoje nesilaikè instrukcijų, sutiko, kad Tautų Sąjunga Lietuvos ir Lenkijos ginčą išspręstų plebiscito būdu, ir neprieštaravo, kad plebiscitas būtų organizuojamas Lietuvos sostinèje Vilniuje. Siekdami išsiaiškinti, ar tai tiesa, išanalizuosime įvykius

${ }^{29}$ Voldemaras, A. Ar susidès Mažoji Lietuva su didžiaja? Tauta. 192008 17, Nr. 39, p. 1. 
chronologiškai, atkreipdami dèmesị i Lietuvos ir Lenkijos konflikto eigą, remdamiesi užsienio reikalų ministro J. Purickio nurodymais ir viešais pranešimais, A. Voldemaro pareiškimais ir telegramomis bei Tautų Sąjungos pozicija.

Pasikeitus jègų pusiausvyrai Sovietų Rusijos ir Lenkijos kare, Lenkijos kariuomené perejo ì puolimą ir priartejjo prie Lietuvos sienų, prasidejo kariuomenių susidūrimai. Lenkijos atstovai pulkininkas Mieczyslawas Mackiewiczius ir kapitonas Adamas Römeris 1920 m. rugpjūčio $26 \mathrm{~d}$. buvo atvykę ì Kauną, siekdami sudaryti karinę konvenciją. Vykstant deryboms Kaune rugpjūčio 27 d., Lenkijos II armijos vadovybė išleido operatyvinị ịsakymą, kuriame buvo nurodyta, kad iki bolševikų ofenzyvos lenkų valdyti plotai ir toliau priklauso Lenkijai. Lietuviams tų plotų neapleidžiant geruoju, buvo įsakyta jų dalinius nuginkluoti. Rugpjūčio $28 \mathrm{~d}$. lenkų II armijos I pėstininkų pulkas užèmé Augustavą, o ten buvusią Lietuvos kariuomenès X pèstininkų pulko kuopą nuginklavo ir internavo. Rugpjūčio 30 d. lenkai pradejo pulti visą Marijampolès barą ${ }^{30}$. Lietuvos ir Lenkijos derybos Kaune nutrūko.

1920 m. rugsejjo 5 d. Lenkijos užsienio reikalų ministras Eustachijus Sapieha įteikè notą Tautų Sąjungai, prašydamas sulaikyti Lietuvos Vyriausybę nuo karo su broliška lenkų tauta ${ }^{31}$. Notoje Lietuva buvo kaltinama 1919 m. gruodžio 8 d. linijos pažeidimu, etninių lenkų žemių užèmimu, Lietuvos ir Sovietų Rusijos kariuomenès bendradarbiavimu ir Lenkijos kariuomenès puolimu. Lenkija buvo Tautų Sąjungos narè, todèl negalėjo skelbti karo, prieš tai neišmėginusi visų priemonių taikiai išspręsti konfliktą. Pagal Tautų Sąjungos statutą, Lenkija, skelbdama karą Lietuvai, ịtraukia ị karą visas Tautų Sąjungos valstybes.

${ }^{30}$ Lesčius, V. Lietuvos kariuomene nepriklausomybès kovose. Vilnius, 2004, p. 304-305.

3119200905 Lenkijos užsienio reikalų ministro E. Sapiehos nota Tautų Sajungos Generaliniam sekretoriui E. Drummondui. Profesorius Augustinas Voldemaras. Raštai, p. 225-227. 
Gavusi Lenkijos notą, rugsèjo 10 d. Tautų Sąjunga atsiuntẻ Lietuvai, kuri nebuvo Tautų Sąjungos naré, kvietimą sutikti, kad Lietuvos ir Lenkijos konfliktą spręstų Tautų Sąjunga, ir dalyvauti šios organizacijos posėdžiuose ${ }^{32}$. Lietuvos Vyriausybė sutiko ir paskyrė atstovu prie Tautų Sąjungos prof. A. Voldemarą. Jau rugsejo 13 d. jis išvažiavo ì Paryžių, kur buvo numatyti parengiamieji pasitarimai prieš Tautų Sąjungos plenarinị posėdį Ženevoje ${ }^{33}$. A. Voldemarui buvo pavesta išsakyti Lietuvos poziciją. Rugsèjo $15 \mathrm{~d}$. apie 11 val. jis prisistatė ị Paryžiuje vykstantị Tautų Sąjungos Tarybos posėdį.

$1921 \mathrm{~m}$. spalio $15 \mathrm{~d}$. Steigiamojo Seimo posėdyje kalbėdamas apie rugsejjo $5 \mathrm{~d}$. Lenkijos notą, A. Voldemaras pabrèžè, kad lenkai tikèjosi lengvai laimèti, nes jų pusèje buvo Anglijos ir Prancūzijos spauda, be to, jie manè, kad lietuviai nespès pasirengti posėdžiui. Jo aiškinimu, užsienyje buvo manoma, kad yra slapta Lietuvos ir Sovietų Rusijos sutartis, nes teritorijas, kurias iš lenkų paimdavo sovietai, tuoj pat užimdavo lietuvių kariuomenè. Jis nurodè, kad paprastai tokiose situacijose diplomatija turi pranešti, kokiu tikslu užimamos teritorijos, tačiau Lietuva to nepadarè. Lenkija akcentavo, kad lietuvių kariuomenė peržengè gruodžio $8 \mathrm{~d}$. liniją ir užèmė Lenkijai priskirtus Suvalkus ir Augustavą. Užsienyje susidarè nuomonė, kad Lietuva su Sovietų Rusija puola Lenkiją ir nežinia, kur sustos.

Rugsèjo 16 d. Tautų Sąjungos Tarybos posėdyje Paryžiuje svarstytas Lietuvos ir Lenkijos konfliktas. Posėdžio pirmininkas Paulas Hymansas pranešè, kad Lenkija kreipèsi ị Tautų Sąjungą, prašydama tarpininkavimo, kadangi nori išvengti karo su Lietuva.

Lietuvos atstovas A. Voldemaras pasakè kalbą, kuri vèliau pareiškimo forma buvo ịteikta Tautų Sąjungos generaliniam sekretoriui Ericui Drummondui. Atsakydamas ị Lenkijos atstovo kaltinimą dèl Lietuvos ir Sovietų Rusijos kariuomenių bendradarbiavimo, Lietuvos

${ }^{32}$ Lietuva Tautų Sąungoj. Laisvè. 192010 17, Nr. 215, p. 2.

${ }^{33}$ Lietuva ir Tautų Sajunga. Lietuva. 192009 13, Nr. 197, p. 1; 19201015 I sesijos 51 posèdis. Steigiamojo Seimo darbai. Kaunas, 1920-1922. 
atstovas A. Voldemaras neslëpé, kad prie Lietuvos ir Sovietų Rusijos sutarties pasirašytas susitarimas, leidęs sovietų kariuomenei užimti Lietuvos teritoriją, kurią prieš tai buvo užèmusi Lenkija. Jis aiškino, kad Lietuva, tik siekdama būti neutrali, sutiko su šia Rusijos sąlyga. Sovietai siūlè lietuviams patiems sulaikyti lenkus arba neprieštarauti tam, kad sovietų kariuomenė, vydama lenkus, užimtų Lietuvai sutartimi pripažintas teritorijas. Po šių argumentų A. Voldemaras pacitavo minètą sutarties priedą. Anot jo, Lietuvos delegacija sutiko su šiuo reikalavimu, tačiau pridèjo esminę sąlygą, kad rusų kariuomenè būtų atitraukta, kai tik išnyks karinis ir strateginis jos buvimo reikalas. A. Voldemaras aiškino, kad šis pareiškimas buvo pasirašytas sovietams esant prie Lietuvos sostinès vartų. Jie, dar iki pasirašant Taikos sutartị, buvo užėmę didelę teritorijos dalị, ị kurią pretendavo Lietuva. Taikos derybos vyko Maskvoje ir dèl netiesioginio ryšio sunkumų Lietuva net nežinojo, ar sovietai pasirašys sutartị. Atrodẻ, kad Lietuvos likimas priklausè nuo sovietų malonès, nes jie galèjo užimti ne tik Vilnių, bet ir Kauną, tačiau nepasinaudojo šia proga. A. Voldemaro teigimu, lietuviai prašè besitraukiančių lenkų, kad perduotų Vilnių Lietuvos kariuomenei, tačiau lenkai reikalavo priimti arbitražą dèl Vilniaus klausimo, su kuo lietuviai negalejo sutikti. Liepos $13 \mathrm{~d}$. lenkų kariuomené paliko Vilnių, tačiau i jị žygiuojanti Lietuvos kariuomenè ties Vieviu sulaukè lenkų pasipriešinimo. Tai sukliudè pralenkti Raudonąją armiją, tad ši pirmoji įžengè i Vilnių ${ }^{34}$.

A. Voldemaras paaiškino, kad Lietuva negalëjo laikytis nustatytos linijos, apie kurią nieko nežinojo. Jis sakè, kad apie tą liniją nerašè pasaulio spauda, o Didžiosios Britanijos užsienio reikalų ministras lordas Georgas Nathanielis Curzonas per savo misiją pranešè Lietuvos Vyriausybei, kad Didžiosios Britanijos Vyriausybe žino tik vieną demarkacijos liniją - vadinamąją Focho liniją. O ši linija nesutampa

3419200916 Lietuvos atstovo Tautų Sąungoje A. Voldemaro nota Tautų Sajungos generaliniam sekretoriui E. Drummondui. Profesorius Augustinas Voldemaras. Raštai, p. 232-233. 
su gruodžio 8 d. nustatyta linija pietuose. Jis teigè, kad Lietuvos kariuomenè užèmé tik tuos plotus, kuriuos buvo palikusi Lenkijos kariuomenè, tuo siekdama apsaugoti lietuviškas teritorijas nuo karo ${ }^{35}$. Po šio paaiškinimo ịtampa atslūgo ir nuomonè apie Lietuvą pasikeitè i geresnę pusę.

Rugsèjo $17 \mathrm{~d}$. buvo išrinkta komisija, turejjusi neoficialiai pasitarti, kaip rasti išeitị iš susidariusios padèties. Komisiją sudarẻ Lietuvos ir Lenkijos atstovai, P. Hymansas, keletas žmonių iš Tautų Sąjungos sekretoriato ir Juridinio skyriaus. Lenkijos atstovas atsinešè kitą pareiškimą, kuriame Lietuva jau nebuvo kaltinama bendradarbiavimu su sovietais, tik rašoma, kad jos kariuomenè stovi anapus gruodžio 8 d. nustatytos linijos, todèl kyla karo pavojus. A. Voldemaras pateikè rugsejjo 5 d. Sovietų Rusijos notą, kurioje buvo rašoma, kad Rusija pasiruošusi atitraukti kariuomenę iš Lietuvos teritorijos, jei Lenkija taip pat pripažins Lietuvos neutralitetą. Lenkų atstovas nurodė, kad jiems būtina užimti dalị Lietuvos teritorijos. Tačiau visiems buvo aiš$\mathrm{ku}$, kad neutraliteto pažeidimas iš vienos pusès paskatina neutraliteto pažeidimą iš kitos pusès. A. Voldemaras paklausė, ar Tautų Sąjungos tikslas yra išplèsti karą Lietuvos teritorijoje, ar jị susiaurinti ir padaryti visą Lietuvą neutralią ${ }^{36}$. Buvo pasiūlyta, jei sovietai garantuos, kad laikysis neutralumo Lietuvos atžvilgiu, tuomet ir lenkai turès pažadèti gerbti Lietuvos neutralumą. Tuo metu sovietai dar buvo Gardine, todèl I. Paderewskis pasikvietė $\mathfrak{i}$ posėdị generalinio štabo atstovą ir paklausé, ar Lenkija gali priimti tokias sąlygas. Lenkijos generalinio štabo atstovas sutiko priimti sąlygas, todèl atrodè, kad neliko kliūčių Lietuvai ir Lenkijai susitarti. Lietuva ịsipareigojo apie nutarimą pranešti sovietams ir gauti jų garantijas, tačiau siekiant igyvendinti šị nutarimą reikejjo sustabdyti karo veiksmus tarp abiejų šalių.

Rugsèjo 19 d. Tautų Sąjungos Tarybos posėdyje pirmininkas L. Bourgeois skaitè rezoliucijos projektą ir, perskaitęs punktą, kuria-

${ }^{35}$ Lietuva Tautų Sajungoj. Laisve. 1920-10-17, Nr. 215, p. 2.

3619201015 I sesijos 51 posèdis. Steigiamojo Seimo darbai. Kaunas, 1920-1922. 
me buvo kalbama apie karo veiksmų nutraukimą, paklausė pirmiausia Lietuvos atstovo A. Voldemaro, ar jis gali Lietuvos Vyriausybés vardu pažadèti, kad Lietuva nekariaus su Lenkija. A. Voldemarui atsakius teigiamai, L. Bourgeois to paties paklausé Lenkijos atstovo I. Paderewskio. Šis apgailestaudamas pareiškè, kad tokio pažado duoti negali, nes Lenkijos generalinis štabas davė griežčiausias instrukcijas, kad Lenkijos atstovas tokių sąlygų nepriimtų. Kilo didžiulis nepasitenkinimas. Lenkijos atstovui buvo pasiūlyta susisiekti su generaliniu štabu, kad šis pakeistų instrukcijas.

Rugsejjo 20 d. Tautų Sąjungos plenumo posėdyje buvo perskaitytas naujas projektas. Iš diskusijų komisijoje buvo aišku, kad lenkai nepriims sąlygos nutraukti karo veiksmus. A. Voldemaras oficialiai kreipèsi ị pirmininką, prašydamas paklausti, ar Lenkijos atstovas igaliotas priimti Tautų Sąjungos nutarimą. Lietuvos atstovas siekè parodyti Tautų Sąjungai, kad Lenkija yra tikroji agresorè, todèl jis pareiškė, kad Lietuva priima nutarimą nutraukti karo veiksmus, ir prašė, kad Tautų Sąjunga paragintų Lenkiją tą padaryti. Jo kalba buvo užprotokoluota ${ }^{37}$. P. Hymansas sakė, kad Tautų Sąjungos Taryba tik nustatys laikinąją demarkacijos liniją, o galutinai klausimą turès spręsti Lietuvos ir Lenkijos konferencija. Jis atkreipè dèmesị, kad Lietuvai priklausančios Gardino ir Lydos apskritys yra užimtos Sovietų Rusijos kariuomenès, ir sakè manąs, kad Lenkija dèl šios aplinkybès gali pasinaudoti Lietuvos teritorija tolesniam karui su Sovietų Rusija. Posėdžio pabaigoje Tautų Sąjungos Taryba vienbalsiai prièmé rezoliuciją, kurioje kreipèsi ì Lietuvos ir Lenkijos Vyriausybes, kad jos sustabdytų karo veiksmus ir priimtų tokias sąlygas:

1) Lietuva, pasilikdama teisę $\mathfrak{i}$ teritoriją, laikinai sutinka laikytis 1919 m. gruodžio 8 d. linijos ir atitraukti savo kariuomenę, esančią i vakarus nuo jos.

3719201015 I sesijos 51 posèdis. Steigiamojo Seimo darbai. Kaunas, 1920-1922. 
2) Lenkija priima pasiūlymą saugoti tų žemių neutralitetą, pasilikdama savo teritorines teises, jei Lietuva gaus iš Sovietų Rusijos garantijas taip pat laikytis neutraliteto šiose žemèse.

3) Tautų Sąjungos Taryba siūlo Lietuvai ir Lenkijai išrinkti komisiją, kuri vietoje stebėtų tų sąlygų vykdymą.

4) I komisiją pasiūlyta įtraukti Japonijos ir Ispanijos atstovus ${ }^{38}$.

A. Voldemaras padekojo Tautų Sąjungai už intervenciją i Lietuvos ir Lenkijos konfliktą, o ypač pirmininkui L. Bourgeois, ir pridūrè, kad, nors karas atrodè neišvengiamas, dabar jis tvirtai įsitikinęs, jog Lietuvos Vyriausybè padarys viską taikai pasiekti. Jis pareiškè, kad visa lietuvių tauta nori taikos, ir tikino laikąs geru ženklu tai, kad pranešejas P. Hymansas yra atstovas didvyriškos belgų tautos, kuri, susigrąžinusi nepriklausomybę ir pasirašydama pirmąją tarptautinę sutartị, paskelbè apie savo valstybès neutralitetą.

I. Paderewskis, A. Voldemarą pavadinęs ne savo priešininku, bet draugu, pripažino, kad konflikto jau nebèra. Jis aiškino, kad vienas iš daugelio Tautų Sąjungos uždavinių yra saugoti mažas tautas nuo didelių tautų agresyvumo. Jo teigimu, lenkų tauta yra per daug maža, kad ją galima būtų priskirti prie didelių tautų, bet per daug didelè, kad ją būtų galima laikyti maža tauta. I. Paderewskis apgailestavo dèl Lenkijos konflikto su „seserimi“ Lietuva ir pabrèžè, kad Lenkija nori ne tik išvengti karo, bet ir parodyti gerą pavyzdị kitoms šalims, todèl kreipèsi ị Tautų Sąjungą, o ši sutiko tarpininkauti ir prièmé greitą ir teisingą sprendimą. I. Paderewskis pažadejo, kad Lenkijos Vyriausybè laikysis Tautų Sąjungos nutarimo, ir ištiesęs ranką Lietuvos atstovui palinkèjo „tvirto, nuolatinio draugingumo“"39.

Ši rezoliucija buvo nusiųsta abiem konfliktuojančioms šalims ir šios rezoliuciją ratifikavo. P. Klimas atsiminimuose rašè, kad P. Hymansas tuo metu nesiorientavo, koks yra Lietuvos ir Lenkijos santykių rezginys, todèl jo raporte buvo daug neaiškumų ir netikslumų

${ }^{38}$ Lietuvių lenkų klausimas Tautų Sajungoje. Lietuva. 1920-10-03, Nr. 14, p. 2.

39 Ten pat. 
dèl demarkacijos linijų ir sienų. Jis tvirtino, kad A. Voldemaras tų netikslumų neatitaisè ir "gal net pats kiek pripainiojo“, tačiau nepateikè jokių detalių ${ }^{40}$.

Tuo pačiu metu - 1920 m. rugsejo 16-18 d. Kalvarijoje vyko Lietuvos ir Lenkijos derybos, deja, jos buvo nevaisingos. Rugsèjo $21 \mathrm{~d}$. Lietuvos užsienio reikalų ministras J. Purickis nusiuntė Lenkijos užsienio reikalų ministrui E. Sapiehai notą, kurioje rašè, kad, nevaisingai pasibaigus Lietuvos ir Lenkijos deryboms Kalvarijoje, Lietuvos Vyriausybè sutinka perduoti Lietuvos ir Lenkijos ginčą spręsti Tautų Sąjungai. Be to, igalioja prof. A. Voldemarą atstovauti Lietuvos interesams ir veikti Lietuvos Vyriausybės vardu ${ }^{41}$. I šią notą Lenkijos užsienio reikalų ministras rugsejjo $22 \mathrm{~d}$. atsakè nota, kurioje apkaltino Lietuvą Lenkijai priklausančių teritorijų okupavimu, Tautų Sąjungos nutarimų nevykdymu ir pareišké, kad Lenkijos kariuomenè pasilieka laisvas rankas ${ }^{42}$.

Lenkija nesilaikè savo pažadų - rugsèjo 22 d. jos kariuomenè netikètai atakavo Lietuvos kariuomenę Suvalkijoje, pralaužè frontą ir paėmė ị nelaisvę apie 1700 Lietuvos kareivių ${ }^{43}$. Šis puolimas, ̣̇vykdytas iš karto vos tik prièmus Tautų Sąjungos nutarimą, buvo didelis smūgis Tautų Sąjungai ir pademonstravo, kad Lenkija, būdama Tautų Sąjungos narè, nevykdo jos nutarimų. P. Klimas rašè, kad Lietuvos delegatas prie Tautų Sąjungos A. Voldemaras, pranešdamas apie Lenkijos kariuomenès puolimus visame demarkacijos linijos ruože, kèlè klausimą, ar Lenkijos Vyriausybè nesupranta tikrosios Tautų Sąjungos priimtos rezoliucijos prasmès, ar ji sąmoningai ją iškraipo ${ }^{44}$.

Rugsèjo 25 d. A. Voldemaras atsiuntė Vyriausybei telegramą, vèliau ji buvo paskelbta laikraštyje „Lietuva“. Telegramoje nurodo-

${ }^{40}$ Klimas, P. Iš mano atsiminimu, p. 260.

${ }^{41}$ Notos dèl Lietuvių Lenkų santykių. Lietuviai nori Lietuvių Lenkų klausimą taikiai išspręsti. Lietuva. 192009 26, Nr. 208, p. 1.

42 Notos dèl Lietuvių Lenkų santykių. Lenkai skelbia karą Lietuvai. Lietuva. 192009 26, Nr. 208, p. 1.

${ }^{43}$ Vilkelis, G. Lietuvos ir Lenkijos santykiai Tautu Sajungoje, p. 68.

${ }^{44}$ Klimas, P. Iš mano atsiminimu, p. 263. 
ma, kad Tautų Sąjungos nariai džiaugiasi, jog Lietuva prièmė Tautų Sąjungos tarpininkavimo pasiūlymą, ir nori kuo skubiau sudaryti Kontrolès komisiją. Tai, kad Lenkijos kariuomenė puolè Lietuvos kariuomenę, sukèlè Tautų Sąjungos nepasitenkinimą ir net pasipiktinimą, nes Lenkija sulaužè Tautų Sąjungos nutarimus. A. Voldemaras rašè, kad Tautų Sąjunga rengia kolektyvinę notą Lenkijai ${ }^{45}$.

Tą pačią dieną Tautų Sąjungos pirmininkas L. Burgeois nusiuntė Lenkijos Vyriausybei notą, kurioje pareiškè nusistebejjimą lenkų elgesiu, reikalavo duoti lietuviams laiko ịvykdyti Tautų Sąjungos nutarimus ir aiškino, kad pačios Lenkijos interesas yra išlaikyti draugiškus santykius su Lietuva ${ }^{46}$. Lenkijos atstovas I. Paderewskis paaiškino, kad jo šalis griebėsi karo veiksmų, siekdama apsisaugoti nuo bolševikų atakų, ir pasiūlè Lietuvai pratęsti derybas Suvalkuose.

1920 m. rugsejjo 30 d. prasidejo Lietuvos ir Lenkijos derybos Suvalkuose. Lietuva šiuo atveju padarè didelę nuolaidą, nes Lenkija nesilaikẻ savo ịsipareigojimų ir sustiprino karo veiksmus prieš Lietuvos kariuomenę, jie tęsèsi beveik visą derybų laikotarpị. 1920 m. rugsèjo 30 d. Tautų Sąjungos Tarybos pirmininkas L. Bourgeois pasikvietė A. Voldemarą su I. Paderewskiu ir paklausė, ar abi šalys ir toliau pageidauja Tautų Sąjungos tarpininkavimo. Abu atstovai atsakè teigiamai $^{47}$. Posédyje buvo nutarta $\mathfrak{i}$ Lenkijos ir Lietuvos karo veiksmų zoną pasiųsti Tautų Sąjungos Kontrolès komisiją, kuri turèjo prižiūrèti Tautų Sąjungos nutarimų vykdymą.

Suvalkų derybos vyko sunkiai. Jas išgelbèjo spalio 4 d. ị Suvalkus atvykusi Tautų Sąjungos Kontrolès komisija ir pareikalavusi tuoj pat sustabdyti karo veiksmus. Lenkijos delegacija ši kartą sutiko tai padaryti. Užsienio reikalų viceministras P. Klimas dar spalio 5 d. pra-

45 Paskutinès politikos valandos. Lietuvių lenkų klausimas Tautų Sajungoje. Lietuva. 192009 30, Nr. 211, p. 1.

${ }^{46}$ Klimas, P. Iš mano atsiminimu, p. 263.

47 Vilkelis, G. Lietuvos ir Lenkijos santykiai Tautu Sajungoje, p. 69; Klimas, P. Iš mano atsiminimu, p. 267. 
nešė Lietuvos delegacijai, kad dalis Lenkijos kariuomenès pasiskelbs maištininkais ir užims Vilnių, o vèliau nuvers ir „Kauno valdžią“48. Ši informacija buvo panaudota derybose, bet nesustabde Lenkijos kariuomenès.

Spalio 4 d. Lietuvos atstovas A. Voldemaras Tautų Sąjungos Tarybos pirmininkui ịteikè protestą prieš Lenkiją, kuri buvo sustabdžiusi karo veiksmus tik dviem valandoms, nors buvo žadejusi apskritai vengti susidūrimų su Lietuvos kariuomene ${ }^{49}$. Lietuvos atstovas pasakè, kad Lenkija vykdo savo planus užimti Vilnių. Spalio 7 d. Suvalkuose buvo pasirašyta sutartis, nustačiusi naują demarkacijos liniją, tačiau, dar neịsigaliojusi, sutartis buvo sulaužyta. Tik pasirašius Suvalkų sutartị Lietuvos delegacija sužinojo, kad Lenkijos kariuomenè pradejo naują akciją Lydos-Vilniaus kryptimi. Lietuvos delegacija Tautų Sąjungos Kontrolès komisijai įteikè protestą prieš Lenkijos kariuomenès veiksmus. Bandydama sukliudyti Lenkijos planams, spalio 8 d. ši komisija išvyko ị Vilnių, tačiau tai nepadejo - spalio 9 d. L. Żeligowskio kariuomenè, apsimetusi maištininkais, okupavo Vilnių ${ }^{50}$.

A. Voldemaro perspejimas pasitvirtino - spalio $8 \mathrm{~d}$. jis gavo telegramą iš Lietuvos užsienio reikalų ministerijos, kad lenkai sumanè „bermontiadą“, norèdami atskirti vieną kariuomenės dalị ir, pavadinę ją iš lietuvių sudaryta kariuomene, užimti Vilnių. Lietuvos atstovas tą pačią dieną Tautų Sąjungos pirmininkui nusiuntè notą, kurioje informavo, kad Lenkija sulaužè visus savo pažadus, ir nurodè, kad tai ne tik juridinis dalykas, bet ir humanizmo klausimas. A. Voldemaras perspejo, kad lenkams užėmus Vilnių prasidės žydų žudynės ir kils badas, nes tik Lietuva gali išmaitinti Vilnių. Notos pabaigoje Lietuvos atstovas prašè pareikalauti iš Lenkijos Vyriausybės pasiaiškinimo

${ }^{48}$ Skirius, J. Lietuviu visuomenininkas ir diplomatas Bronius Kazys Balutis. Vilnius, 2001, p. 195-196.

${ }^{49}$ Politikos žinios. Lietuvos atstovo protestas Tautų Sajungoje. Laisvė. 192010 06, Nr. 236, p. 2.

${ }^{50}$ Łossowski, P. Stosunki polsko-litewski w latach 1918-1920. Warszawa, 1966, p. 288. 
ir pažado, kad kaltininkas bus nubaustas ${ }^{51}$. P. Klimas atsiminimuose rašè, kad A. Voldemaras Paryžiuje dieną naktị bombardavo Tautų Sąjungos pirmininką L. Burgeois dèl neregètos lenkų klastos ir veidmainystės. Jo tvirtinimu, nuolatinis lenkų priekaištavimas, kad lietuviai dangsto rusų kariuomenę, neteko prasmès spalio $5 \mathrm{~d}$. Lenkijai ir Rusijai pasirašius sutartị dèl paliaubų ${ }^{52}$.

Spalio 9 d. A. Voldemaras Tautų Sąjungos Tarybos pirmininką supažindino su atvykusiu Lietuvos užsienio reikalų ministru J. Purickiu. Savo atsiminimuose J. Purickis rašè, kad pasikalbejjimas su L. Burgeois sukosi apie lenkų iškeltą Lietuvai tariamo neutraliteto laužymo bylą ir didesnio ịspūdžio jam nepaliko ${ }^{53}$.

Spalio $9 \mathrm{~d}$. vakare A. Voldemaras išvažiavo iš Paryžiaus, o spalio 10 d. jau Berlyne telegrafu gavo iš Tautų Sąjungos Lenkijos generalinio štabo pranešimą, kad sukilęs generolas L. Żeligowskis užėmė Vilnių. Iš Berlyno jis išsiuntė skubią telegramą, prašydamas palyginti jo spalio $8 \mathrm{~d}$. notą su spalio 9-10 d. Lenkijos generalinio štabo praneši$\mathrm{mu}$, ir paragino griežtai reaguoti ị tokị Tautų Sąjungos narès Lenkijos elgesi $i^{54}$.

1920 m. spalio 12 d. Lietuva Tautų Sąjungai išsiuntė prašymą, kad ją priimtų šios organizacijos nare. Sutikdama su Tautų Sąjungos pasiūlymu Lietuva tikèjosi, kad bus priimta ị Tautų Sąjungą ir pripažinta de jure. Tokių vilčių suteikè ir Tautų Sąjungos generalinis sekretorius E. Drummondas, pranešęs Lietuvos užsienio reikalų ministerijai, kad lapkričio 15 d. Ženevoje bus svarstomas Lietuvos priėmimo ị Tautų Sąjungą klausimas. Jis prašè atsiųsti nepriklausomybès paskelbimo ir kitų valstybių pripažinimo de jure ar de facto dokumentų kopijų ${ }^{55}$.

5119201015 I sesijos 51 posėdis. Steigiamojo Seimo darbai. Kaunas, 1920-1922.

52 Klimas, P. Iš mano atsiminimu, p. 271.

53 Dr. Juozas Purickis-Vygandas. Iš Vilniaus pagrobimo laikų. Vilniaus klausimas 1918-1922 liudininkų akimis, p. 45.

5419201015 I sesijos 51 posėdis. Steigiamojo Seimo darbai. Kaunas, 1920-1922; Lietuva Tautų Sajungoj. Laisve. 192010 17, Nr. 215, p. 2.

${ }^{55}$ Lietuvos klausimo sprendimas. Lietuvos ūkininkas, 192010 24-30, Nr. 41, p. 6. 
Spalio 15 d. A. Voldemaras informavo Steigiamąji Seimą, kad spalio 20 d. Briuselyje vyks Tautų Sąjungos posėdis, kuriame bus svarstomas Lenkijos klausimas. Jo aiškinimu, Lenkijos Vyriausybè negalès aiškintis, kad Vilnių užèmęs generolas jos neklauso, nes „tame ne-

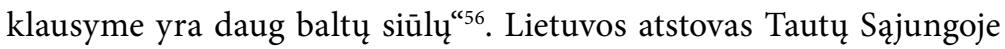
pareiškè, kad sukilęs generolas išbrauktas iš Lenkijos kariuomenès, tačiau padave atsistatydinimo pareiškimą. Sukilimą A. Voldemaras pavadino komedija, ị kurią Tautų Sąjunga turès reaguoti, tačiau taip pat atkreipe dèmesĭ, kad griežčiausių priemonių Lenkijai ji negalès taikyti, nes oficialiai Lenkija karo nepaskelbè. Vis dèlto A. Voldemaras neabejojo, kad Tautų Sąjunga privers Lenkiją likviduoti Vilniaus avantiūrą.

„Lietuvos ūkininkas" rašè, kad spalio $17 \mathrm{~d}$. A. Voldemaras išvyko i Briuselį․ . Užsienio reikalų viceministras P. Klimas siuntė jam telegramas, informuodamas apie L. Żeligowskio puolimo pavojų Lietuvai. Spalio 21 d. A. Voldemaras pranešè Užsienio reikalų ministerijai, kad Tautų Sąjunga gali pasiūlyti Lietuvos ir Lenkijos konfliktą spręsti plebiscitu. P. Klimas apie tai pranešè į Londoną užsienio reikalų ministrui J. Purickiui ir pridūrè, kad Lietuvos Vyriausybè sutikimo dar nèra davusi ${ }^{58}$.

Lietuvos ir Lenkijos ginčas Tautų Sąjungoje buvo pradètas svarstyti $1920 \mathrm{~m}$. spalio $25 \mathrm{~d}$. ir buvo nagrinejjamas tris dienas ${ }^{59}$. Posèdžiams pirmininkavo Belgijos užsienio reikalų ministras P. Hymansas, Lietuvai atstovavo prof. A. Voldemaras, Lenkijai - Simonas Aszkenazy. Spalio $26 \mathrm{~d}$. A. Voldemaras įteikè Tautų Sąjungos Tarybos pirmininkui notą, kurioje pabrèžè, kad Lenkijos Vyriausybe ir karinè vadovybè nuolat bendradarbiauja su L. Żeligowskiu, ir pateiké faktų apie

5619201015 I sesijos 51 posėdis. Steigiamojo Seimo darbai. Kaunas, 1920-1922.

${ }^{57}$ Lietuvos klausimo sprendimas. Lietuvos ūkininkas, 192010 24-30, Nr. 41, p. 6.

58 Vilkelis, G. Lietuvos ir Lenkijos santykiai Tautu Sajungoje, p. 78.

${ }^{59}$ Lenkų siekimai ir Tautų Sajungos nusprendimas. Úkininkas. 192011 7-13, Nr. 43, p. 2. 
kareivius bei ginkluotę, gabenamus iš Varšuvos ị Vilnių, taip pat pridejjo Lietuvos kariuomenės paimtų lenkų belaisvių liudijimų apie i̊sakymą veržtis gilyn ị Lietuvą. Lietuvos delegatas konstatavo, kad L. Żeligowskis vykdo Lenkijos Vyriausybès planus okupuoti visą Lietuvą ir vèliau inscenizuoti jos savanorišką prisijungimą prie Lenkijos. A. Voldemaro teigimu, šis klastingas karas yra pavojingesnis Lietuvai už atvirą karą, nes Lenkija to griebėsi norèdama išvengti Tautų Sąjungos sankcijų. Jis prašè skubiai sušaukti Tautų Sąjungos plenumą, kad šis apsvarstytų sankcijų pritaikymą Lenkijai pagal 16-ąji straipsnį ${ }^{60}$. Spalio $27 \mathrm{~d}$. posėdyje pirmasis kalbèjo A. Voldemaras, jis pateikè dokumentų, įrodančių, kad Lenkijos Vyriausybė padèjo L. Żeligowskiui organizuoti Vilniaus užgrobimą, ir pareikalavo, kad Tautų Sąjunga pritaikytų savo îstatų 16-ąji paragrafą, numatantị ekonominę ir finansinę blokadą panašiais atvejais. Šis straipsnis turèjo būti pritaikytas, jei L. Żeligowskis būtų atsisakęs evakuoti savo kariuomenę ir atiduoti Vilnių Lietuvos Vyriausybei. P. Klimas rašè, kad reikalavimas Lenkijai pritaikyti sankcijas net nebuvo svarstomas. Tautų Sąjungos Tarybos nariai klausinejjo, ar tikrai Lenkijos Vyriausybe tiekia „karinę medžiagą "L. Żeligowskiui, ar Lenkija gins tą generolą ir panašiai ${ }^{61}$.

Lenkijos atstovas S. Aszkenazy aiškino, kad L. Żeligowskis tokią akciją padarè dèl netinkamo „Kauno valdžios“ elgesio su Vilniaus gyventojais ir sutarčių su vokiečiais bei bolševikais. Jo teigimu, Lenkijos Vyriausybė skiria generolą L. Żeligowskį, nepaklausiusị savo valdžios ir todèl vertą pasmerkimo, nuo „Želigovskio Lietuvos piliečio, kuriam užjaučia visa lenkų tauta“62. Toliau jis aiškino, kad, Lenkijai ir „Kauno Lietuvai“ sustabdžius karinius veiksmus ir Lenkijai pasirašius paliaubas su Sovietų Rusija, lietuvių ir lenkų konfliktas iš esmès pasikeitė ir yra kitokio pobūdžio, negu buvo tuo metu, kai su juo susipažino Tautų Sąjungos atstovai. Po šio pareiškimo buvo padaryta pertrauka,

${ }^{60}$ Klimas, P. Iš mano atsiminimu, p. 277.

${ }^{61}$ Ten pat, p. 279.

${ }^{62}$ Tautų Sajungos posėdis spalių 27 d. Lietuva. 192011 06, Nr. 242, p. 3. 
tuomet P. Hymansas pateikè plebiscito pasiūlymą. Lenkijos atstovas su šiuo siūlymu iš principo sutiko, tačiau dèl detalių pareiškè norịs pasitarti su savo Vyriausybe. P. Klimas, nors pats nedalyvavo posėdyje, atsiminimuose rašè, kad A. Voldemaras, „lyg praradęs pirmykštị savo reiklumą", posèdžio gale paklausè, ar plebiscitas numatomas tik Vilniuje, ar visame krašte. P. Hymansas atsakè, kad visame krašte ${ }^{63}$.

Spalio 27 d. telegramoje J. Purickiui ì Londoną P. Klimas rašè: „Voldemaras praneša, kad Tautų Sąjunga Vilniaus klausimą sutinka rišti plebiscitu, nes būk mūsų valdžia neseniai sutikusi su tuo."64 P. Klimas tvirtino, kad Vyriausybè tokio sutikimo nedavė, ir prašè J. Puricki apie tai informuoti A. Voldemarą. Spalio 28 d. Tautų Sąjungos posėdyje buvo priimtas nutarimas siūlyti Lietuvai ir Lenkijai nesutarimus spręsti plebiscitu. P. Klimas rašè, kad tai buvo pirmas fiasko Tautų Sąjungos istorijoje, nes ji ne tik nenuteise agresoriaus, bet jam nusileido ir privertė nusileisti lietuvius ${ }^{65}$. Lietuvos atstovas A. Voldemaras, negavęs P. Klimo telegramos (gavęs J. Purickio pritarimą spalio 28 d. P. Klimas išsiuntė A. Voldemarui į Briuselį telegramą, kurioje rašè, kad spręsti Vilniaus klausimą plebiscitu Vyriausybė niekada nesutiko ir nesutinka ${ }^{66}$ ), plebiscito pasiūlymui neprieštaravo, tačiau dar reikèjo gauti oficialų Vyriausybès pritarimą. Tautų Sąjunga reikalavo atsakyti per 2 dienas, bet Lietuvos atstovas pareikalavo 10 dienų termino ${ }^{67}$. Matyt, A. Voldemaras pareikalavo ilgesnio termino todèl, kad susisiekti su Užsienio reikalų ministerija ir J. Purickiu nebuvo taip paprasta. Tuo metu Lietuva susisiekdavo telegrafu su Tautų Sąjunga per pasiuntinybę Berlyne, be to, užsienio reikalų ministras J. Purickis buvo užsienyje ${ }^{68}$.

${ }^{63}$ Klimas, P. Iš mano atsiminimu, p. 281.

6419201027 P. Klimo telegrama J. Purickiui ị Londoną. LCVA, f. 383, ap. 7, b. 92, 1. 246

${ }^{65}$ Klimas, P. Iš mano atsiminimu, p. 281.

${ }^{66}$ Vilkelis, G. Lietuvos ir Lenkijos santykiai Tautu Sajungoje, p. 78.

67 Tautų Sajungos posėdis spalių 27 d. Lietuva. 192011 06, Nr. 242, p. 3.

${ }^{68}$ Klimas, P. IŠ mano atsiminimu, p. 256. 
Spalio 30 d. J. Purickis telegramoje P. Klimui rašè, kad Tautų Sąjungos sprendimą reikia priimti, priešingu atveju Lietuva gali netekti Antantès ir Anglijos paramos. Anglai patare priimti pasiūlymą kuo skubiau, nes per 10 dienų lenkai gali užimti Kauną ${ }^{69}$. Žinios iš Lietuvos buvo grèsmingos: A. Voldemaras iš Užsienio reikalų ministerijos gaudavo pranešimų apie papildomas lenkų kariuomenès dalis, ginkluotę ir amuniciją, vežamas į Vilnių, buvo perspẻjimų, kad lenkai ruošiasi pulti Kauną ${ }^{70}$.

Lapkričio $1 \mathrm{~d}$. Lietuvos atstovas Anglijoje grafas Alfredas Tiškevičius, J. Purickio pavestas, Tautų Sąjungos generaliniam sekretoriui E. Drummondui išsiuntė telegramą, kurioje rašè, kad Lietuvos Vyriausybe sutinka su spalio $28 \mathrm{~d}$. Tautų Sąjungos nutarimu, tačiau taip pat pareiškè pageidavimą, kad plebiscitas būtų organizuojamas Seinuose, Punske ir ị rytus nuo Curzono (1919 m. gruodžio 8 d.) linijos, bet plebiscitas turètų būti daromas už linijos, kadangi $1920 \mathrm{~m}$. spalio 7 d. Lenkija pasirašè Suvalkų sutartị ir tuo pripažino, kad teritorija ị šiaurę nuo Curzono linijos yra lietuviška, ir pasmerke generolo L. Żeligowskio žygi, kai jo vadovaujama kariuomenè tą liniją peržengè. Telegramoje taip pat buvo atkreiptas dèmesys ị nelygiateisę Lietuvos ir Lenkijos padètí, kadangi Lietuva nèra pripažinta de jure ${ }^{71}$.

Lapkričio $3 \mathrm{~d}$. telegramoje, dar nežinodamas apie J. Purickio atsakymą, perduotą per A. Tiškevičių, A. Voldemaras patarè, kad ratifikacijos notoje J. Purickis primintų Tautų Sąjungos pareigas, kurios rezervuoja Lietuvos teises anapus Curzono linijos, ir nurodytų, kiek Lietuva gali nusileisti. Taip pat jis prašè leisti kartu su Tautų Sąjungos nutarimo ratifikavimo dokumentais itteikti notą, kurioje nurodys išsamesnius motyvus. A. Voldemaras rašè, kad belgai abejoja, ar Lietu-

${ }_{69} 19201030$ J. Purickio telegrama Užsienio reikalų ministerijai. LCVA, f. 383, ap. 7, b. $92,1.238$.

${ }^{70}$ Pranešimai iš Vilniaus. LMAB RS, f. 172, b. 706, 1.1.

7119201101 Lietuvos atstovo Londone A. Tiškevičiaus raštas URM viceministrui P. Klimui ir telegramos TS sekretoriui vertimas. LCVA, f. 383, ap. 7, b. 90, 1. 166. 
va bus priimta į Tautų Sąjungą. Taip pat jis jaute pareigą pasakyti, kad Lietuvos pozicija Tautų Sąjungoje yra tokia žema todèl, kad Lietuvos valdžia neturi jokios politikos, laiku nedaromi reikalingi žingsniai arba daromi klaidingi. „Jei taip tęsis, prašysiu mane paliuosuoti“, baigè jis ${ }^{72}$.

A. Voldemaras nebuvo informuotas apie A. Tiškevičiaus notą ir apie ją sužinojo iš P. Chardigny. Lapkričio $5 \mathrm{~d}$. telegramoje jis prašè su Tautų Sąjunga bendrauti tik per jị, nes J. Purickio nurodymu siųsta A. Tiškevičiaus nota padarẻ blogą ispūdị ${ }^{73}$. Pasirodo, kad minètoje notoje Suvalkų sutarties interpretacija prieštaravo jos tekstui, todèl A. Voldemaras prašè suteikti jam igaliojimus notą pataisyti. Tokie igaliojimai jam buvo suteikti ${ }^{74}$.

Lapkričio 6 d. nota A. Voldemaras patvirtino Lietuvos sutikimą ir pridejo, kad vèliau jis pasilieka teisę pateikti pastabų, susijusių su rezoliucijos ratifikavimu. Lenkija atsakè lapkričio $7 \mathrm{~d}$., prašydama plebiscitą ịvykdyti kuo paprasčiau ir kuo greičiau ${ }^{75}$.

J. Purickis atsiminimuose minejo, kad su plebiscito pasiūlymu sutiko A. Voldemaras, o jis, apie tai sužinojęs, bandè A. Voldemarui skambinti telefonu, tačiau Briuselyje jo jau nerado. Užsienio reikalų ministrui paskambinus ị Kauną, viceministras P. Klimas atsakè, kad A. Voldemaras viską pranešè „post factum“. J. Purickis rašè, kad jis negalejo nepriimti plebiscito, kai Lietuvos atstovas jau buvo pareiškęs principinị savo sutikimą ${ }^{76}$. Kaip matome, buvęs užsienio reikalų ministras visą kaltę už plebiscito prièmimą suvertė Lietuvos

7219201103 A. Voldemaro telegrama J. Purickiui. LCVA, f. 383, ap. 7, b. 92, 1. 229.

${ }^{73}$ Ten pat, 1. 228.

7419201106 A. Voldemaro telegrama P. Klimui. LCVA, f. 383, ap. 7, b. 92, 1. 225; J. Purickio telegrama A. Voldemarui. LCVA, f. 383, ap. 7, b. 92, 1. 226.

75 1920-12-04 P. Klimo pranešimas iš Ženevos J. Purickiui Nr. 2. LCVA, f. 383, ap. 7, b. 92, 1. 97; Vilkelis, G. Lietuvos ir Lenkijos santykiai Tautu Sajungoje, p. 79; Klimas, P. Ǐs mano atsiminimu, p. 282;

${ }^{76}$ Dr. Juozas Purickis-Vygandas. Iš Vilniaus pagrobimo laikų. Vilniaus klausimas 1918-1922 liudininkų akimis, p. 74. 
atstovui Tautų Sąjungoje A. Voldemarui, nors galutinị atsakymą davè jis pats.

Lapkričio $5 \mathrm{~d}$. Lietuvos Vyriausybès posėdyje, dalyvaujant P. Klimui, buvo parengta instrukcija A. Voldemarui, kurioje numatyta plebiscitą rengti i vakarus nuo trečiosios demarkacinès linijos, neịtraukiant i šią teritoriją Vilniaus ${ }^{77}$. Lietuva turèjo būti pripažinta de jure, taip sulyginant abiejų šalių tarptautinị statusą, o lenkų kariuomenė išvesta iš ginčytinos teritorijos. Vyriausybè tikèjosi, kad A. Voldemarui Tautų Sąjungoje pavyks atidèti plebiscitą. Vis dèlto didžiosios valstybès nebuvo pasirengusios priimti Lietuvą ì Tautų Sąjungą. 1920 m. lapkričio 5 d. telegramoje užsienio reikalų ministrui J. Purickiui A. Voldemaras rašè, kad L. Bourgeois patarè atšaukti Lietuvos prièmimo ị Tautų Sąjungą klausimą iš posėdžio darbotvarkès, nes prièmimo sunku tikètis, o nepriemimas pakenks Lietuvai. A. Voldemaras pažadejo nieko nedaryti be aiškaus nurodymo tuo klausimu ${ }^{78}$.

1920 m. lapkričio 15 d. A. Voldemaras grižzo ị Kauną ir apie Lietuvos bylą Tautų Sąjungoje papasakojo „Lietuvos“ laikraščio bendradarbiui. Atsakydamas ị klausimą dèl plebiscito teritorijos, jis aiškino, kad teritorija ị rytus nuo Curzono linijos apima ir Vilnių, nes visas konfliktas sukasi apie Vilnių. A. Voldemaras sakè, kad jokių sąlygų dèl plebiscito nebuvo galima kelti, nes Tautų Sąjunga reikalavo atsakyti taip arba ne. I klausimą, ar Tautų Sąjunga negalètų padaryti įtakos, kad Lietuva būtų pripažinta de jure, A. Voldemaras atsakè, jog tai kitas klausimas. Jo nuomone, pats faktas, kad valstybei nustatomos sienos, jau yra pripažinimas, nes būtų nonsensas, jei „valstybei būtų nustatomos sienos, o pačios valstybès nebūtų “79. Jo teigimu, negalima reikalauti prieš plebiscitą sulyginti kontragentus, nes kiekviena

19201105 P. Klimo instrukcija A. Voldemarui. LMAB RS, f. 172, b. 167, 1. 4.

7819201105 A. Voldemaro telegrama užsienio reikalų viceministrui P. Klimui iš Paryžiaus. LCVA, f. 383, ap. 7, b. 92, 1. 228.

79 Paskutinès politikos valandos. Grịžta prof. Voldemaras. Lietuva. 192011 16, Nr. 250, p. 1; Prof. A. Voldemaras apie Vilniaus laimę. Lietuva. 192011 19, Nr. 253, p. 2. 
šalis turi savo pliusų ir minusų. Be to, A. Voldemaro teigimu, Tautų Sąjunga, siekdama užtikrinti tvarką ir plebiscito organizavimo sąlygas, rezervavo sau teisę nustatyti plebiscito zonas ir klausimą, kokios valstybès kariuomenẻ bus pasiųsta ị šią teritoriją. Jis neabejojo, kad plebiscitas bus naudingas Lietuvai, jei bus sudarytos sąlygos, kurios leis žmonèms laisvai balsuoti. A. Voldemaro nuomone, lenkų spauda nervinasi, nes nesitiki, jog plebiscitą laimès Lenkija, todèl ji reikalauja atviro balsavimo, kad galètų įbauginti žmones. Jis buvo ịsitikinęs, kad Vilnius be Lietuvos yra „ekonominis nonsensas“ ir vilniečiams visiškai nenaudinga jungtis prie Varšuvos. Jam atrodè, kad Vilniaus krašto žmonèms ịkyrèjo lenkų plèšimai ir rekvizicijos, o Lietuvos Vyriausybė, valdydama Vilnių, rekvizicijų nedarè, davė duonos ir užtikrino tvarką, todèl miesto gyventojų simpatijos bus Lietuvos puseje.

A. Smetona buvo kitokios nuomonès. $1920 \mathrm{~m}$. lapkričio $5 \mathrm{~d}$. straipsnyje „Žmonių atsiklausimas - plebiscitas“ jis rašè, kad nelygiavertẻ Lietuvos ir Lenkijos padètis vers žmones rinktis tarptautiniu mastu pripažintą Lenkiją, o ne Lietuvą, kuri neaišku, ar bus pripažinta, ar atiteks Rusijai arba Vokietijai ${ }^{80}$. Jis nuogąstavo, kad Lietuva gali netekti Vilniaus ir pietinès dalies, o tuomet ir savo nepriklausomybès. A. Smetonos žodžiais, neatsargu buvo ginčytinų žemių klausimu taip toli nueiti, o dar neatsargiau būtų toliau ji ta pačia kryptimi tęsti.

Lietuvoje kilo pasipiktinimas dèl plebiscito priemimo. P. Klimas rašè, kad „nerimastavo ir ginčijosi Steigiamojo Seimo nariai, raukèsi ir gąstavo Griniaus kabinetas su Purickiu, užsienio reikalų ministru, triukšmavo jaunimas ir spauda"81. A. Voldemaras buvo kaltinamas, kad be Vyriausybės žinios prièmė Tautų Sąjungos pasiūlymą. Grịžęs iš užsienio Steigiamojo Seimo delegacijos narys M. Sleževičius, duodamas interviu "Lietuvos“ žurnalistui, pareišké, kad Lietuvos atstovo prie Tautų Sąjungos A. Voldemaro sutikimas daryti plebiscitą

${ }^{80}$ Lėnas [Antanas Smetona]. Žmonių atsiklausimas - plebiscitas. Tauta. 192011 05, Nr. 55, p. 1.

${ }^{81}$ Klimas, P. Iš mano atsiminimu, p. 283. 
Lietuvos rytinèse žemèse, okupuotose L. Żeligowskio, yra skaudus smūgis Lietuvai, ir paneigè informaciją, kad ši sutikimą davė Lietuvos Vyriausybė ar Seimo delegacija ${ }^{82}$. Vis dèlto pirmiau pateikti faktai ir archyviniai dokumentai rodo, kad A. Voldemaras, laiku negavęs P. Klimo telegramos, tik neprieštaravo plebiscito siūlymui, o galutinị sprendimą prièmė užsienio reikalų ministras J. Purickis, manydamas, kad neprièmusi siūlymo Lietuva gali netekti Antantès ir Anglijos paramos.

\section{A. Voldemaro taktika derybose dèl plebiscito}

Prièmusi Tautų Sąjungos pasiūlymą dèl plebiscito, Užsienio reikalų ministerija tuoj pat informavo visuomenę apie Lietuvos keliamas sąlygas. Lapkričio 5 d. laikraštyje „Lietuva“ užsienio reikalų viceministras P. Klimas patvirtino, kad Lietuva prièmé Tautų Sąjungos pasiūlymą ir pareiškè, jog plebiscitas bus teisingas tik tada, kai iš okupuotų sričių bus atitraukta Lenkijos kariuomenè ir atlyginti jos padaryti nuostoliai. Plebiscitas, Užsienio reikalų ministerijos nuomone, negali būti daromas Lietuvos sostinejje Vilniuje. Be to, Lietuva turi būti pripažinta de jure ${ }^{83}$.

1920 m. lapkričio 15 d. Ženevoje prasidejo visuotinis Tautų Sąjungos narių susirinkimas, $\mathfrak{i}$ jị vèl buvo pasiųstas A. Voldemaras ir Seimo Ūkininkų sąjungos frakcijos atstovas Valdemaras Vytautas Čarneckis. Beje, A. Voldemaras tik lapkričio 15 d. grị̌zo ị Kauną, todèl tą dieną Ženevoje vykusiame Tautų Sąjungos posedyje Lietuvos ir Lenkijos klausimas nebuvo svarstytas ${ }^{84}$.

Lapkričio 17 d. Lietuvos socialistų liaudininkų demokratų partijos ir Lietuvos valstiečių sąjungos frakcijos bloko posėdžio protokole rašoma, kad Seimo Užsienio reikalų komisija norèjo, kad ì Ženevą

${ }^{82}$ Iš pasikalbejjimo su St. Seimo nariais. Lietuva. 192011 21, Nr. 255, p. 2.

83 Dienos klausimu. Lietuva. 192011 05, Nr. 241, p. 1.

${ }^{84}$ Politikos žinios. Dèl Lietuvos klausimo Tautų Sajungos taryboje. Laisvé. 192011 18, Nr. 240, p. 2. 
vyktų šešių asmenų delegacija, tačiau A. Voldemaras griežtai tam paprieštaravo, aiškindamas, kad jam patarejjų nereikia ${ }^{85}$. Tą patvirtino lapkričio 16 d. krikščionių demokratų laikraštis „Laisvë“. Jame buvo rašoma, kad Tautų Sąjungos posėdyje bus svarstoma Lietuvos ir Lenkijos byla, taip pat Lietuvos, Latvijos ir Estijos priemimas i Tautų Sąjungą, todèl ị Ženevą Lietuva siunčia delegaciją, kurios pirmininkas yra prof. A. Voldemaras, o nariai - užsienio reikalų viceministras P. Klimas, ministras be portfelio žydų reikalams Maksas Soloveičikas, Lietuvos atstovas Prancūzijoje Oskaras Milašius, Lietuvos atstovas Šveicarijoje Vaclovas Sidzikauskas ir Seimo narys V. Čarneckis ${ }^{86}$. Laikraštis skelbè, kad V. Čarneckis jau išvažiavo į Ženevą, o kiti nariai išvyks po kelių dienų. Vadinasi, A. Voldemaras pasiekè, kad delegacija būtų sumažinta iki 2 narių - jo ir V. Čarneckio, kuris jau buvo išvažiavęs į Ženevą. A. Voldemaras buvo ne kartą viešai kritikavęs į užsienị siunčiamas gausias Steigiamojo Seimo delegacijas.

Lapkričio 18 d. užsienio reikalų ministras J. Purickis kartu su Seimo Užsienio reikalų komisija parengė delegacijai Ženevoje instrukciją, kurioje buvo numatyta teritorija ir sąlygos, būtinos plebiscitui vykdyti ${ }^{87}$. Instrukcijoje nurodyta, kad teritorija, kurioje daromas plebiscitas, apima ne tik plotą, pripažintą Lietuvai liepos $12 \mathrm{~d}$. sutartimi su Sovietų Rusija, bet ir Slonimo žemę (Gardino srityje), Dysnos ir Vileikos apskritis rytuose bei pietuose ị vakarus nuo gruodžio $8 \mathrm{~d}$. linijos teritoriją Vižainis-Punskas-Seinai ir rytinę Augustavo apskrities dalị bei Gardino gubernijos dalị. Plebiscitas nedaromas neabejotinai lietuviškose srityse, visų pirma ị šiaurę nuo Švenčionių ir Varẻnos apylinkèje. I vakarus plebiscito plotas apima ginčijamas vietas, kurio-

8519201117 Steigiamojo Seimo LSLDP ir LVS frakcijų bloko protokolas. LMAB RS, f. 199-22, 1. 103-104.

${ }^{86}$ Politikos žinios. Lietuvos byla Tautų Sajungoje. Laisvė. 192011 16, Nr. 238, p. 2; Politikos žinios. Voldemaras grịžta Kaunan. Laisve. 192011 17, Nr. 239, p. 2.

8719201118 J. Purickio instrukcija A. Voldemarui. LCVA, f. 383, ap. 7, b. 90, 1. 9; 19201117 Steigiamojo Seimo LSLDP ir LVS frakcijų bloko protokolas. LMAB RS, f. 199-22, 1. 103. 
se nebuvo Steigiamojo Seimo rinkimų. Praplèsti plebiscito teritoriją ị baltarusiškas žemes pasiūlè ị Kauną atvykusi baltarusių delegacija, už tai pažadejjusi plebiscito teritorijoje gyvenusių baltarusių paramą Lietuvai, o lapkričio $11 \mathrm{~d}$. Lietuvos Vyriausybe pasirašė sutartị su Vaclovo Lastouskio vadovaujama Gudų Liaudies Respublikos Vyriausy$b^{88}$. Taip pat numatyta balsavimą organizuoti suskirsčius teritoriją $\mathfrak{i}$ keturias zonas. Balsavimas turèjo būti slaptas, iš teritorijos, kurioje turèjo vykti plebiscitas, reikejjo išvesti lenkų kariuomenę, o tvarką turẻjo prižiūrèti neutralios šalies kariuomenè. Dar viena būtina sąlyga prieš plebiscitą ginčytinoje teritorijoje suorganizuoti rinkimus ị vietos savivaldybes $^{89}$. Instrukcijoje nebuvo užsiimta apie tai, kad plebiscito negalima vykdyti Vilniaus mieste. Šią instrukciją A. Voldemaras turbūt gavo išvykdamas į Ženevą, nes lapkričio 19 d. J. Purickis jau siunté jam telegramą su instrukcijos pakeitimais: „Instrukcijos pirmas punktas pakeičiamas taip: plebiscitas nedaromas Vilniaus sostinès srity, o tai yra visoj trečioj zonoj. Motyvai, kad lietuvių tauta negali rizikuoti savo sostine dèl laikino žmonių apkvailinimo. Be to, Rusija mūsų sutikimą galès išnaudoti prieš mus. Kai toks siūlymas nepraeis, pareikškit savo nepasitenkinimą arba protestą ir skaitykit Sąjungos nutarimą kaip priverstą. ${ }^{\text {"90 }}$

Iš paskutinès formuluotès galima numanyti, kad instrukcija buvo pakeista iš anksto tikintis, kad toks siūlymas nebus priimtas. Istorikè Vilma Bukaitè rašè, kad greičiausiai užsienio reikalų ministras J. Purickis iš pradžių ịtikino Ministrų kabinetą sutikti, kad plebiscitas būtų rengiamas Vilniuje, tačiau kitą dieną, galbūt ịkalbètas P. Klimo, sprendimą pakeité ${ }^{91}$. Gintautas Vilkelis nurodè, kad sprendimo pakeitimą lèmè padètis lietuvių ir lenkų fronte: L. Żeligowskio kariuome-

${ }_{88} 19201117$ Steigiamojo Seimo LSLDP ir LVS frakcijų bloko protokolas. LMAB RS, f. 199-22, 1. 103; Vilkelis, G. Lietuvos ir Lenkijos santykiai Tautu sajungoje, p. 80 .

8919201118 J. Purickio instrukcija A. Voldemarui. LCVA, f. 383, ap. 7, b. 90, 1. 9.

9019201119 J. Purickio telegrama A. Voldemarui. LCVA, f. 383, ap. 7, b. 90, 1. 8.

91 Bukaitè, V. Nepriklausomybès akto signataras Petras Klimas. Vilnius, 2016, p. 176. 
nė veržèsi ị Lietuvos gilumą, tačiau lapkričio 19 d. prasidėjo Lietuvos kariuomenès kontrpuolimas ir L. Żeligowskio kariuomenė buvo priversta atsitraukti ${ }^{92}$.

Ta pačią lapkričio 19 d. užsienio reikalų viceministras P. Klimas išsiuntė A. Voldemarui 2 telegramas. Pirmoje jis rašè, kad memorialo tekstą, visus priedus (sutartis, pripažinimą, originalius tekstus ir visą kitą medžiagą) turi V. Čarneckis. Antroje P. Klimas nurodè, kad ministerija turi daugybę naujų pareiškimų su tūkstančiais Seinų, Punsko ir kitų vietovių, esančių anapus Curzono linijos, gyventojų parašų, ir siūlè atsiųsti, jei reikès ${ }^{93}$.

1920 m. lapkričio 20 d. Tautų Sąjungos Taryba kreipèsi ị Lietuvos ir Lenkijos Vyriausybes, kviesdama susitarti dèl ploto, kuriame bus rengiamas plebiscitas, nustatymo ${ }^{94}$. Gruodžio $4 \mathrm{~d}$. raporte užsienio reikalų ministrui $\mathrm{P}$. Klimas rašè, kad lapkričio $23 \mathrm{~d}$. Lietuvos delegacijos pirmininkas A. Voldemaras savo notoje, adresuotoje Tautų Sąjungos Tarybos pirmininkui L. Burgeois, atkreipe dèmesị $\mathfrak{i}$ Vilniaus lietuviškumą ir neteisètas lenkų pretenzijas ị tą Lietuvos sostinę, bet nepaminejo, kad Lietuva nesutinka su plebiscitu Vilniuje. Taip pat A. Voldemaras nenurodė plebiscito zonų, nieko neminejjo dèl Slonimo žemès, Seinų, Punsko, Dysnos ir Vileikos apskričių. P. Klimas rašè: „Voldemaras išrado net visai nereikalingą mūsų Kaune paruoštą memorialą tuo reikalu ir visai ji užmetè. Todèl ir jo pasirodymas pavèlintas." ${ }^{\text {"95 }}$

Atsiminimuose P. Klimas detaliau apibūdino lapkričio $23 \mathrm{~d}$. notos turinị. A. Voldemaras joje dèstè, kad Vilniaus lietuviškumą liudija Lietuvos istorija, todèl jis yra neginčijamas, nei lietuvių tauta,

92 Vilkelis, G. Lietuvos ir Lenkijos santykiai Tautu Sajungoje, p. 81.

9319201119 P. Klimo telegrama A. Voldemarui. LCVA, f. 383, ap. 7, b. 90, 1. 4;

Ten pat, 1.3 .

94 Paskutinès politikos valandos. Pataria lietuviams ir lenkams susitarti. Lietuva. 1920-11-27, Nr. 260, p. 1.

9519201204 P. Klimo raportas J. Purickiui iš Ženevos Nr. 2. LCVA, f. 383, ap. 7, b. $92,1.97$. 
nei Lietuvos Vyriausybė neabejoja „dèl jų neatimamų teisių ị senąją

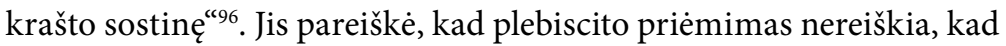
Lietuva pripažista lenkų pretenzijų teisètumą. Toliau notoje jis dėstė, kad, priimdama Tautų Sąjungos rezoliuciją, Lietuvos Vyriausybė ją interpretuoja taip, kaip ji pati apsibrèžè, t. y. kad plebiscito zona turi apimti tik etniniu atžvilgiu ginčijamą teritoriją. Be to, notoje rašoma, kad Lietuvos Vyriausybè negalès pripažinti plebiscito rezultatų, jei nebus užtikrinta balsavimo laisvè. Taip pat A. Voldemaras nurodè spalio $28 \mathrm{~d}$. rezoliucijos prièmimo juridines pasekmes - priimdama šią rezoliuciją Tautų Sąjunga, o kartu ir visos jai priklausančios valstybės pripažino de jure Lietuvos nepriklausomybę. Jis paaiškino, kad, jeigu Tautų Sąjunga imasi nustatyti galutines sienas tarp Lenkijos ir Lietuvos, vadinasi, pripažįsta Lietuvos valstybę. Jeigu ji mano, kad Lietuvos valstybė yra laikina, tai tuomet ir sienos yra laikinos, bet tada Tautų Sąjunga turi atsisakyti spalio $28 \mathrm{~d}$. rezoliucijos ir grįžti prie rugsejo 20 d. rezoliucijos, kurioje buvo numatyta nustatyti demarkacijos liniją. Taip pat jis primine, kad Versalio sutartyje parašyta, jog galutines Lenkijos sienas nustatys didžiosios valstybès ir jų sąjungininkès, todèl apsièmusi nustatyti šias sienas Tautų Sąjunga dabar vykdo didžiųjų valstybių teisę. P. Klimas rašè, kad šia nota A. Voldemaras „iš pamatų griovė visą Tautų Sąjungos Tarybos pastatą “97. Kaip matome, P. Klimas kritiškai vertino A. Voldemaro notą $1920 \mathrm{~m}$. pabaigoje raporte J. Purickiui ir labai palankiai apie ją atsiliepè atsiminimuose, rašytuose 1957-1962 metais. Panašu, kad praejjus daugiau kaip 40 metų P. Klimas kitaip vertino A. Voldemaro pastangas ginti Lietuvos interesus Tautų Sąjungoje.

Akivaizdu, kad A. Voldemaro ir J. Purickio nuomonès dèl taktikos Tautų Sąjungoje nesutapo. Notoje A. Voldemaras griežtai nepareiškè, kad Lietuva nenori plebiscito Vilniuje, ir nieko nepasakè apie zonas ir Lietuvos pretenzijas ị baltarusiškas žemes.

${ }^{96}$ Klimas, P. Iš mano atsiminimu, p. 283-284.

${ }^{97}$ Ten pat, p. 283. 
Lapkričio 23 d. Lietuva gavo Tautų Sąjungos sekretoriaus parengtą memorandumą dèl Lietuvos prièmimo ị Tautų Sąjungą. Lapkričio pabaigoje atvykęs į Briuselị, P. Klimas Tautų Sąjungos sekretoriate peržiūrèjo Lietuvos ir Lenkijos bylos dokumentus ir raporte J. Purickiui pareiškej, kad memorandumas buvo rašytas be A. Voldemaro itakos ir pagalbos, nes jame buvo nemažai klaidų ir netikslumų. Jis rašè: „<...> jeigu Voldemaras nebūtų tenkinęsis išimtinai formaliais žygiais ir būtų užmezgęs darbo santykius su sekretoriatu ir tais asmenimis, kurie memorialą dirbo, tas memorialas būtų išejęs daug tikslesnis ir teisingiau bei plačiau mūsų reikalą būtų nušvietęs. Gi post factum Voldemaras savo notoje (11 27) turejo tiktai ištaisyti memorialo klaidas." ${ }^{\text {"98 }}$

A. Voldemaras mané, kad nereikia skubėti Tautų Sąjungai pristatyti plebiscito projekto, ir siūlè palaukti, kol savo projektą pristatys Lenkija. Lapkričio 26 d. telegramoje J. Purickiui jis nurodè, kad „projekto pristatymas lygus prisipažinimui, kad abejojame dèl lietuviškumo Lithuania Propria" ${ }^{\text {"99. }}$. Artimiausiu metu A. Voldemaras žadèjo Tautų Sąjungai pateikti plebiscito Slonime ir Seinuose reikalavimus. Taip pat jis rašè neturintis vilčių, kad Lietuva bus priimta ị Tautų Sąjungą, todèl siūlè atsiimti prašymą. Jo teigimu, priimta ị Tautų Sąjungą, Lietuva turès Lenkiją ginti nuo Rusijos. Jo nuomone, Tautų Sąjunga bijos motyvuoto Lietuvos pareiškimo atsièmimo, todèl bus nuolaidesnè. Atsakydamas ị šią telegramą J. Purickis dèstè, kad būtų geriau, jei Tautų Sąjunga atidètų Lietuvos prièmimą, jei šiuo metu negali priimti. Jos teigimu, plebiscito siūlymą Lietuva prièmé, nes tikèjosi prieš plebiscitą būti priimta ị Tautų Sąjungą ir pripažinta de jure, taip sulyginant Lietuvos ir Lenkijos galimybes. Jei žmonèms reikès pasirinkti esančią ar abejotiną valstybę, laimès Lenkija. J. Purickis nurodè A. Voldemarui siekti L. Żeligowskio kariuomenès evakuacijos

9819201204 P. Klimo raportas J. Purickiui Nr. 2. LCVA, f. 383, ap. 7, b. 92, 1. 97. 9919201126 A. Voldemaro telegrama J. Purickiui. LCVA, f. 383, ap. 7, b. 92, 1. 166. 
ir pridūrè, kad tas teritorijas, prižiūrima Kontrolès komisijos, galètų užimti Lietuvos kariuomenè $\dot{e}^{100}$.

Lapkričio 27 d. J. Purickis ị Ženevą pasiuntè užsienio reikalų viceministrą P. Klimą ir Tomą Naruševičių ${ }^{101}$. Tą pačią dieną Volfo agentūra pranešè, kad Ženevoje A. Voldemaras ir S. Aszkenazy sutiko su plebiscitu Vilniaus srityje $\mathrm{e}^{102}$. Gruodžio $3 \mathrm{~d}$. ELTA paneigè prieš kelias dienas Volfo agentūros paskelbtą informaciją, kad Lietuvos atstovas A. Voldemaras sutiko su plebiscitu Vilniuje, ir paskelbè, kad Lietuvos Vyriausybė sutinka su plebiscitu brèžiant liniją Varèna-Bastūnai ${ }^{103}$. Anot oficialių Ženevos pranešimų, plebiscito teritorija dar nebuvo svarstyta, nes laukiama pasiūlymų iš Lietuvos ir Lenkijos. ELTA informavo, kad kol kas nè viena šalis jų nebuvo ịteikusi. Tautų Sąjunga per Kontrolès komisiją pasiūlè konfliktuojančioms šalims tiesiogiai pasitarti dèl plebiscito vykdymo. Abi šalys ši pasiūlymą prièmė. Be to, ELTA pranešè, kad i Varšuvą derètis dèl belaisvių ruošiasi važiuoti Lietuvos delegacija, kuriai bus pavesta pasitarti ir dèl plebiscito.

Lapkričio 29 d. buvo pasirašytos paliaubos su L. Żeligowskio kariuomene, tam tarpininkavo Tautų Sąjungos Karinès kontrolès komisija. Tą pačią dieną J. Purickis telegramoje A. Voldemarui rašè, kad Kontrolès komisijos pirmininkas ir sekretorius yra „beveik lenkų agentai“, ir prašè stengtis pakeisti visą komisiją ar bent pirmininką ${ }^{104}$. A. Voldemaro teigimu, Lietuva be reikalo „mèto pinigus“, nes V. Čarneckis Ženevoje sėdi be darbo, tokia pati bus ir P. Klimo, ir T. Naruševičiaus padètis. Taip pat telegramoje A. Voldemaras rašè, kad Lenkijos

${ }^{100} 19201126$ J. Purickio šifruota telegrama A. Voldemarui. LCVA, f. 383, ap. 7, b. 92, 1. 204.

${ }^{101}$ Paskutinès politikos valandos. P. Klimas ir T. Naruševičius važiuoja Ženevon. Lietuva. 192011 27, Nr. 260, p. 1.

${ }^{102}$ Telegramos. Dèl plebiscito Vilniuje. Lietuva. 192011 30, Nr. 262, p. 2.

${ }^{103}$ Paskutinès politikos valandos. Neteisingi gandai dèl plebiscito Vilniuj. Lietuva. 192012 04, Nr. 266, p. 1.

${ }^{104} 19201129$ J. Purickio šifruota telegrama A. Voldemarui. LCVA, f. 383, ap. 7, b. 92, 1. 160 . 
ir Lietuvos konfliktą sprendžia Tautų Sąjungos Taryba, o plebiscito teritorija bus nustatoma, kai bus pateikti Lenkijos ir Lietuvos projektai. Apie P. Chardigny ir L. Żeligowski jis žadejo pakalbèti su lordu Robertu Cecilliu ${ }^{105}$. Kitoje tos pačios dienos telegramoje A. Voldemaras aiškino, kad ministerijoje klaidingai suprato jo lapkričio $27 \mathrm{~d}$. telegramą dèl noro atsiimti Lietuvos prašymą stoti ị Tautų Sąungą. Jis rašé, kad Lietuvos motyvai, jog Tautų Sąjunga pati neįstengia vykdyti savo nutarimų, gali paveikti taip, kad ji prašys neatsiimti pareiškimo ir nusileis kitais klausimais ${ }^{106}$.

Lapkričio 30 d. vakare P. Klimas ir T. Naruševičius atvyko į Ženevą, tačiau A. Voldemaro nerado, nes jis prieš kelias dienas buvo išvažiavęs i Lozaną. Paskambinę jam telefonu, delegacijos nariai susitarè atvykti pas ji gruodžio 1 dieną ${ }^{107}$.

1920 m. gruodžio 1 d. užsienio reikalų ministras J. Purickis vèl išsiuntė A. Voldemarui ị Lozaną šifruotą telegramą (iššifruota gruodžio 3 d.), perspèdamas, kad Prezidentas ir Vyriausybè prašo visus svarbesnius žingsnius daryti tik pasitarus su delegacijos Ženevoje nariais, „nes tamstos atstovaujami reikalai turi mūsų valstybei pamatinę reikšmę, tada kiekvienas neatsargus žingsnis galètų turèti pragaištingas pasekmes"108.

Gruodžio 2 d. raporte užsienio reikalų ministrui P. Klimas rašè, kad plebiscito Vilniuje nebus galima išvengti, nes visiems aišku, kad „byla sukasi apie Vilnių ir jo likimą“. A. Voldemaras delegacijos nariams aiškino, kad Lietuvos užsienio reikalų ministras, siųsdamas telegramą Tautų Sąjungos pirmininkui L. Burgeois, sutiko, kad Tautų Sąjunga išspręstų Lietuvos ir Lenkijos ginčą, taip pat Lietuva prièmé Briuselio rekomendacijas, sutikdama su plebiscitu visose ginčijamose

${ }^{105} 19201129$ A. Voldemaro šifruota telegrama J. Purickiui. LCVA, f. 383, ap. 7, b. 92, 1. 192.

${ }^{106}$ Ten pat, 1. 193.

${ }^{107} 19201202$ P. Klimo raportas Nr. 1 J. Purickiui. LCVA, f. 383, ap. 7, b. 92, 1. 167. ${ }^{108} 19201201$ J. Purickio šifruota telegrama A. Voldemarui. LMAB RS, f. 172-714, 1. 1 . 
srityse $^{109}$. Anot P. Klimo, A. Voldemaras sakè, kad Lenkija niekada neatsisakè Vilniaus, net Spa konferencijoje. P. Klimo teigimu, lapkričio $1 \mathrm{~d}$. A. Tiškevičiaus notoje nurodytas pageidavimas, kad į šiaurę nuo Suvalkuose nustatytos demarkacijos linijos neturètų būti plebiscito, yra tik Lietuvos Vyriausybės nuomonè, o Lenkijos ir Tautų Sąjungos nuomonė gali būti kitokia. P. Klimas nurodè, kad A. Tiškevičiaus notoje nepaminètos jokios plebiscitui keliamos sąlygos, kurių neįvykdžius būtų galima jo atsisakyti. A. Voldemaras tvirtino, kad Lietuva galèjo rezoliuciją priimti arba atmesti, bet kelti sąlygų ji negalèjo. Jo supratimu, atsisakydama plebiscito, Lietuva atsisakys Tautų Sąjungos. Kaip galimas išeitis iš susidariusios padèties jis nurodè susitarimą su Lenkija arba savo teritorijų atsièmimą karine jèga.

P. Klimas rašè, kad Lietuvos atstovas nebuvo kviečiamas ị svarstymus dèl tarptautinès kariuomenés siuntimo ị plebiscito teritoriją, tačiau nurodè, kad dar bus sprendžiamas klausimas dèl plebiscito zonų, todèl Lietuva turès galimybę išsakyti savo motyvus dèl Vilniaus, nors A. Voldemaras nesitikèjo čia ką nors laimèti. Be to, A. Voldemaras pareiškè, kad Lenkija, pretenduojanti ị lietuviškas žemes, turi pirmoji pateikti plebiscito projektą, nes „mes iš principo negalime statyti plebiscito klausimo savo žemëje “110. Jo manymu, Lietuvos uždavinys bus kritikuoti Lenkijos projektą ir pateikti savo motyvus. Delegacijos nariai paprašè A. Voldemaro parašyti notą, kad iš Lietuvos ir plebiscito teritorijos būtų išvesta L. Żeligowskio kariuomenè.

Lietuvos prièmimo ị Tautų Sąjungą klausimu A. Voldemaras siūlè akcentuoti tai, kad Lenkijai nebuvo pritaikytas 16-asis straipsnis, nors buvo pateikta ịrodymų, kad ji nuolat rèmė L. Żeligowskio kariuomenę ginklais, amunicija ir kariuomenès daliniais. Be to, nebuvo evakuota L. Żeligowskio kariuomenė ir neaišku, ar Lietuvai bus atlyginti nuostoliai. Kol kas neatšauktas Kontrolès komisijos pirmininkas P. Chardigny, reikalavęs Lietuvos nusiginklavimo, kas prieštaravo Briuselio

${ }^{109} 19201202$ P. Klimo raportas Nr. 1 J. Purickiui. LCVA, f. 383, ap. 7, b. 92, 1. 167. ${ }^{110}$ Ten pat, p. 170. 
nutarimams. A. Voldemaras norejjo pareikšti Tautų Sąjungai, kad Lietuva nemato jos pagalbos, kad Tautų Sąunga nepajègi įvykdyti savo rezoliucijos, todèl Lietuvai nèra didelès būtinybès dalyvauti tokioje sąjungoje. A. Voldemaras norejo pagąsdinti Tautų Sąjungą, todèl siekẻ atsiimti Lietuvos prašymą, nurodydamas, kad Tautų Sąjunga suklupo spręsdama pirmą praktišką klausimą ir parodė savo nepajègumą. A. Voldemaras manè, kad toks manevras pagreitintų Lietuvos prièmimą i Tautų Sąjungą arba padètų morališkai, jeigu Lietuva būtų nepriimta ị Tautų Sąungą ${ }^{111}$.

Gruodžio 3 d. telegramoje P. Klimas J. Purickiui rašè, kad Tautų Sąjungoje niekas neabejoja dèl plebiscito Vilniuje, ir pakartojo A. Voldemaro siūlymus, išdèstytus gruodžio $2 \mathrm{~d}$. raporte. Jis rašè, kad A. Voldemaras nepadarè akcijos prieš plebiscitą Vilniuje, aiškindamas, kad, jei kartą Lietuvos valdžia sutiko, negalima atšaukti, galima tik atsisakyti Tautų Sąjungos tarpininkavimo, turint vilties tiesiogiai susitarti su Lenkija ar atsilaikyti karine jèga, tačiau P. Klimas mané, kad tai rizikingas žingsnis ${ }^{112}$. Taip pat P. Klimas rašè, kad A. Voldemaras „padarė žingsnių“ prieš P. Chardigny paskyrimą.

P. Klimas atsiminimuose rašé, kad gruodžio $3 \mathrm{~d}$. A. Voldemaras, įteikdamas Tautų Sąjungos Tarybai notą dèl paliaubų su L. Żeligowskio kariuomene, kandžiai užsiminè, kad Kontrolès komisija jo nesustabdè, bet primygtinai reikalavo pasirašyti paliaubų protokolą, kai Lietuvos kariuomenè atmušè L. Żeligowskio kariuomenès atakas ir vos jo paties nepaėmé ì nelaisvę. Notoje netiesiogiai buvo pasakyta, kad Kontrolès komisija sukliudè Lietuvai atsiimti Vilnių ${ }^{113}$.

Gruodžio 2 d. P. Chardigny Lietuvos Vyriausybei pasiūlè siųsti $\mathfrak{i}$ Varšuvą delegaciją, kuri dalyvautų tiesioginėse derybose, aiškindamas, kad tokị ịsakymą gavo iš Tautų Sąjungos. B. K. Balutis apie tai informavo A. Voldemarą ir prašè patikrinti, ar Tautų Sąjunga davė

${ }^{111}$ Ten pat, p. 171.

112 1920-12-03 P. Klimo telegrama J. Purickiui. LCVA, f. 383, ap. 7, b. 92, 1. 157.

${ }^{113}$ Klimas, P. Iš mano atsiminimu, p. 287. 
Kontrolès komisijai tokị nurodymą ${ }^{114}$. Gruodžio 3 d. A. Voldemaras telegramoje J. Purickiui rašè: „Chardigny reikalavimas delegacijos Varšuvon nepamatuotas. Kontrolès komisija gali tik prižiūrèti sutarimo vykdymą. Grasinkite nutraukti visus ryšius su ja, jei ji kišis. Sutartis su Želigovskiu lenkų naudai, nes pripažįstate skirtumą tarp Želigovskio ir lenkų ir nenurodote evakuacijos."115

Gruodžio 4 d. surengtas Lietuvos delegacijos susirinkimas, jam pirmininkavo A. Voldemaras, dalyvavo T. Naruševičius, V. Sidzikauskas, V. Čarneckis, Oskaras Milašius ir P. Klimas ${ }^{116}$. I delegacijos narių priekaištus, kodèl A. Voldemaras nereagavo ị lenkų pateiktą plebiscito projektą, delegacijos pirmininkas atsakè, kad tie projektai neturi reikšmės, kol jie nèra priimti ir apie juos nepranešta Lietuvos atstovui. Jis pareiškè, kad E. Drummondas pažadèjęs atsiųsti visus Lenkijos dokumentus, todèl, jei tai nepadaryta, Lietuva turès pagrindą pareikšti priekaištų Tautų Sąjungai. Be to, A. Voldemaras teigè, kad tik dabar Tautų Sąjunga paprašè Lenkijos projekto, o ten buvo tik siūlymas, apie kurị Lietuva turès pareikšti savo nuomonę. I delegacijos narių klausimą, ar pavyks išvengti plebiscito, A. Voldemaras atsakè, kad jis neišvengiamas ir Lietuva tik galès „prieštarauti jo rezultatams, jei netiks būdas ir laikas“117. Delegacija svarstè, ką Lietuva galètų daryti susiklosčiusioje situacijoje. Viena išeitis galèjo būti bylos atsièmimas iš Tautų Sąjungos, tačiau ši išeitis buvo iš karto vienbalsiai atmesta, nes Lietuvai būtų kilęs pavojus netekti Tautų Sąjungą sudarančių valstybių paramos ir simpatijų. Antra išeitis - palaukti, kaip klostysis situacija dèl kariuomenès siuntimo ì plebiscito zoną, ir kelti klausimą dèl Lietuvos pripažinimo de jure, kaip buvo išdèstyta A. Voldemaro lapkričio 23 d. notoje. Jeigu Lietuva nepripažįstama de

${ }^{114}$ 1920-12-02 B. K. Balučio telegrama A. Voldemarui. LCVA, f. 383, ap. 7, b. 92 , 1. 155.

${ }^{115} 19201203$ A. Voldemaro telegrama J. Purickiui. LCVA, f. 383, ap. 7, b. 92, 1. 86. ${ }_{116} 19201204$ P. Klimo raportas J. Purickiui Nr. 2. LCVA, f. 383, ap. 7, b. 92, 1. 105. ${ }^{117}$ Ten pat, 1. 105. 
jure, ji atsisako Briuselio nutarimų ir grị̌ta prie Paryžiaus nutarimų, t. y. prašo išvesti naują demarkacijos liniją. A. Voldemarui išvykus delegacijos nariai svarstė dar vieną variantą - sušaukti Lietuvos Steigiamojo Seimo plenumą, kuris pareikštų nepasitikejjimą Vyriausybe, o, jai atsistatydinus, atšauktų A. Voldemarą ir pareikštų nesutikimą su plebiscitu Vilniuje ${ }^{118}$. P. Klimas rašè, kad formalus Lietuvos atstovo A. Voldemaro bendravimas oficialiais raštais ir notomis, turint omenyje silpną Lietuvos tarptautinę poziciją, neduoda daug vilčių pelnyti Tautų Sąjungos narių palankumą. P. Klimas manè, kad jeigu A. Voldemaras būtų daugiau bendravęs su Tautų Sąjungos nariais neoficialiai ir užmezgęs su jais artimesnius santykius, Lietuva būtų galejjusi tikètis daugiau palankumo.

Gruodžio $5 \mathrm{~d}$. A. Voldemaras ịteikè notą su Sovietų Rusijos pasiuntinio A. Akselrodo pareiškimu dèl Tautų Sąjungos planų pasiųsti kariuomenę i plebiscito teritoriją ${ }^{119}$. Jis prašè sustabdyti kariuomenès siuntimą, nes tai pažeis Lietuvos ir Rusijos taikos sutartị ir gali sukelti konfliktą su Rusija. Gruodžio 8 d. P. Klimas telegramoje nurodè, kad Tautų Sąjungos Tarybos posėdis buvo „labai karštas“" ${ }^{120}$. Ši Taryba Lietuvos prašymą sustabdyti kariuomenès siuntimą traktavo kaip spalio 28 d. rezoliucijos nevykdymą ir politikos keitimą. Ji reikalavo išaiškinti rusams, kad siunčiama kariuomenè vykdys policijos pareigas ir nepažeis Lietuvos ir Rusijos sutarties.

Gruodžio 7 d. ELTA paskelbė „Kurjer Poranny“ pranešimą apie Lietuvos ir Lenkijos atstovų išvadas Vilniaus klausimu Tautų Sąjungos Tarybos posėdyje ${ }^{121}$. A. Voldemaras ịrodinėjo, kad Vilnius turi priklausyti Lietuvai istoriškai, statistiškai ir politiškai. Dèl to kilo diskusijų, buvo pasiūlymų šị klausimą perduoti spręsti Tautų Sąjungos

${ }^{118}$ Ten pat, 1.108.

${ }^{119} 19201205$ P. Klimo telegrama Užsienio reikalų ministerijai. LCVA, f. 383, ap. 7, b. $92,1.92$.

${ }^{120} 19201208$ P. Klimo telegrama Užsienio reikalų ministerijai. LCVA, f. 383, ap. 7, b. $92,1.79$.

${ }^{121}$ Užsieniai. Vilnius - Tautų Sajungos posėdyje. Lietuva. 192012 08, Nr. 269, p. 3. 
plenumui. P. Hymansas, atsakydamas ị Lietuvos atstovo argumentus, pareiškè, kad A. Voldemaras turi laikytis lapkričio $9 \mathrm{~d}$. jo priimtų pasiūlymų, o Tautų Sąjungos Taryba gali spręsti Vilniaus problemą tik remdamasi spalio $28 \mathrm{~d}$. Briuselyje priimta deklaracija. S. Aszkenazy klausimą padalino i 5 punktus: 1) teritoriją, 2) plebiscito laiką, 3) plebiscito vykdymą, 4) politinès administracijos klausimą ir 5) kariuomenès klausimą. Jis tikino, kad ị rytus nuo demarkacinès linijos tarp „Kauno Lietuvos“ ir Lenkijos gyvena 180 tūkstančių lenkų. Anot jo, balsavimas gali vykti skirtingu laiku, žmonès gali išdèstyti savo nuomonę susirinkimuose arba per savo atstovus, išrinktus ị Steigiamąji Seimą, taip pat žmonėms reikia suteikti galimybę nuspręsti, ar jie nori susijungimo ar federacijos su kuria nors pasirinkta tauta. S. Aszkenazy prašè palikti dabartinę politinę organizaciją, pasiūlè atitraukti kariuomenę iš plebiscito teritorijos, tačiau prašè, kad L. Żeligowskio kareiviams, kilusiems iš Lietuvos, būtų leista balsuoti.

J. Purickis pradejo abejoti, ar Tautų Sąjunga pajègs išspręsti Lietuvos ir Lenkijos ginčą, ir gruodžio $6 \mathrm{~d}$. telegramoje prašė Lietuvos atstovo Anglijoje A. Tiškevičiaus „pasiteirauti, kaip ị tai reaguos anglų valdžia"122. Anglijos Vyriausybé ị tokị Lietuvos klausimą reagavo labai griežtai ir atsiuntė oficialų raštą, kuriame priminė Lietuvos i̊sipareigojimus Tautų Sąjungai ir pagrasino, kad Lietuva gali netekti paramos $^{123}$. J. Purickis, pats būdamas kaltas, apkaltino A. Tiškevičių atskleidus Anglijos Vyriausybei slaptą instrukciją ir norejo ji atleis$\mathrm{ti}^{124}$. Ir P. Klimas, ir T. Naruševičius rašè, kad „paklausimas anglams buvo didelė klaida“, tačiau manè, kad neteisinga dèl to kaltinti A. Tiškevičių, ir prašè jo neatleisti ${ }^{125}$. Užsienio reikalų ministras nepaklausẻ

12219201206 J. Purickio telegrama A. Tiškevičiui. LCVA, f. 383, ap. 7, b. 92, 1. 84. 12319201212 A. Tiškevičiaus telegramos vertimas. LCVA, f. 383, ap. 7, b. 92, 1. 51-52. ${ }^{124} 19201219$ J. Purickio telegrama ị Londoną A. Tiškevičiui. LCVA, f. 383, ap. 7, b. $92,1.4$.

${ }^{125} 19201216$ P. Klimo telegrama Užsienio reikalų ministerijai; 19201215 T. Naruševičiaus telegrama Užsienio reikalų ministerijai. LCVA, f. 383, ap. 7, b. 92, 1. 13, 23. 
diplomatų patarimo ir atleido A. Tiškevičių, nors jis turejjo nemažai ryšių su Anglijos politikais.

Gruodžio 9 d. šifruotoje telegramoje A. Voldemarui J. Purickis pakartojo, kad Seimas ir valdžia iškèlè griežtą sąlygą plebiscitui - Lietuvos pripažinimą de jure, nes priešingu atveju Lenkija toliau vykdys agitaciją, reikalaudama, kad Europa rinktųsi Lenkiją ar bolševikus. J. Purickis rašè, kad ši aplinkybė tokia svarbi, jog Tautų Sąjunga negalès jos nepriimti ${ }^{126}$. Lietuvos Vyriausybė pasidavė Tautų Sąjungos Kontrolès komisijai ir sutiko pasiųsti ị Varšuvą komisiją derètis dèl plebiscito. J. Purickis nematė nieko blogo, jei Lietuva pasiųs delegaciją ì Varšuvą "pazonduoti dirvą“, ir buvo ịsitikinęs, kad šis Vyriausybès žingsnis „padèties nẻ kiek nemaino“127.

P. Klimas palaikè A. Voldemarą ir gruodžio $12 \mathrm{~d}$. telegramoje rašè J. Purickiui, kad jokiu būdu negalima siųsti delegacijos į Varšuvą, nes pavojinga vesti derybas dẻl plebiscito ir Ženevoje, ir Varšuvoje, mat Ženevoje Tautų Sąjunga griežtai reikalavo L. Żeligowskio kariuomenès evakuacijos. Jis prašè nepasiduoti P. Chardigny spaudimui ir visus jo pasiūlymus pranešti delegacijai, „kad neišeitų nesutikimų“128. P. Klimas taip pat informavo, kad Lietuvos priemimas ị Tautų Sąjungą atmestas, todèl pripažinimo de jure taip pat nebus.

Anot gruodžio $31 \mathrm{~d}$. krikščionių demokratų savaitraščio „Tẻvynès sargas“, sužinojęs, kad Lietuva nepriimta ị Tautų Sąjungą, prof. A. Voldemaras norejjo perskaityti pranešimą Tautų Sąjungos plenumo posėdyje, tačiau Tautų Sąjungos Taryba jam neleido to padaryti ${ }^{129}$. Tautų Sąjunga paskelbė A. Voldemaro parengtą memorialą, kuriame buvo rašoma, kad Lietuva (ne tik Lenkija) buvo tris kartus Prūsijos, Austrijos ir Rusijos padalinta 1772, 1793 ir 1795 metais. Dar jis pareiš-

${ }^{126} 19201209$ J. Purickio šifruota telegrama A. Voldemarui. LMAB RS, f.172-714, 1. 2 .

${ }^{127} 19201211$ J. Purickio telegrama P. Klimui. LCVA, f. 383, ap. 7, b. 92, 1. 53.

${ }^{128} 19201212$ P. Klimo telegrama J. Purickiui. LCVA, f. 383, ap. 7, b. 92, 1. 48.

${ }^{129}$ Iš Tautų Sajungos. Lietuvos reikalai. Tèvynès sargas. 192012 31, Nr. 2, p. 18-19. 
kè, kad dabar Tautų Sąjunga negali Lietuvos apginti nei nuo bolševikų, nei nuo kitų priešų. Be to, Sovietų Rusija pranešè, kad ji nepakęs Antantès kariuomenès buvimo Lietuvos teritorijoje, todèl Lietuva negali priimti Tautų Sąjungos kariuomenès. Jis aiškino, kad bolševikai nori Lietuvą paversti sovietų respublika, ir klausé, jei Lietuva priims Tautų Sąjungos kariuomenę, ar ji apgins Lietuvą. A. Voldemaro kalba sukèlè daug triukšmo.

Tuo metu Lietuvos Vyriausybė nepaklausè A. Voldemaro ir P. Klimo patarimo ir pasiuntė delegaciją ì Varšuvą. Paliaubų su L. Żeligowskiu pasirašymas be jokių sąlygų, kai Ženevoje buvo reikalaujama evakuoti jo kariuomenę, ir delegacijos ị Varšuvą siuntimas labai apsunkimo delegacijos Ženevoje darbą. J. Purickis toliau spaudè Lietuvos delegaciją Ženevoje laikytis instrukcijų - nesutikti su plebiscitu Vilniuje ir reikalauti pripažinimo de jure. Gruodžio $15 \mathrm{~d}$. telegramoje P. Klimui jis rašè: „Iš pranešimų nematyti, ar padarytas griežtas mūsų sąlygų plebiscitui pareiškimas. Tos sąlygos - pripažinimas de jure, plebiscitas - tik ị pietus nuo linijos Varèna-Bastūnai-Molodečna. Tos sąlygos buvo duotos Klimui ir turèjo būti senai TS pareikštos. Jeigu tas nepadaryta, tai neatideliojant reikia padaryti. Tamsta už tai atsakai. "130 Gruodžio 16 d. telegramoje J. Purickis aiškino, kad delegacijos baimè jam nesuprantama ir, jeigu A. Voldemaras nepadarẻ griežto pareiškimo, reikia ji tučtuojau atšaukti ${ }^{131}$.

Tą pačią dieną, turbūt sužinojęs apie J. Purickio reikalavimą, prof. A. Voldemaras išsiuntė jam telegramą, pranešdamas apie savo atsistatydinimą iš pareigų. Telegramoje jis rašè: „valdžios politika ir elgimasis verčia mane atsistatydinti“, ir klausè, kam turètų perduoti visus reikalus, nes Tautų Sąjungai reikia pranešti, kas bus paskirtas vietoje $j^{132}$. Tą pačią dieną P. Klimas pranešè, kad Lietuva, Latvija ir Estija

${ }^{130} 19201215$ J. Purickio telegrama P. Klimui. LCVA, f. 383, ap. 7, b. 92, 1. 8-9.

${ }^{131} 19201216$ J. Purickio telegrama P. Klimui. LCVA, f. 383, ap. 7, b. 92, 1. 7.

13219201216 A. Voldemaro telegrama Užsienio reikalų ministerijai apie atsistatydinimą iš Tautų Sajungos atstovo pareigų. LCVA, f. 383, ap. 7, b. 92, 1. 15. 
nebuvo priimtos ị Tautų Sąjungą, tačiau prašė palikti A. Voldemarą toliau eiti delegacijos pirmininko pareigas ${ }^{133}$.

Tautų Sąjungos Taryba gruodžio $18 \mathrm{~d}$. nutarè vykdyti plebiscitą ginčijamojoje teritorijoje, t. y. Vilniuje ir jo srityje, o balsavimo laisvei užtikrinti nutarè ị šią teritoriją pasiųsti tarptautinị karinị dalinị ${ }^{134}$. Gruodžio 20 d. telegramoje J. Purickiui P. Klimas rašè: „Griežtas išskyrimas Vilniaus bus tolygu atsièmimui iš Sąjungos. “135 Lietuvos delegatams reikejjo laviruoti toliau.

1921 m. sausio pradžioje grịžęs iš Tautų Sąjungos posẻdžio Ženevoje, A. Voldemaras davė interviu žurnalistams. Jis aiškino, kad Ženevoje domimasi Lietuvos ir Lenkijos konfliktu, ir nurodè, kad daugelio šalių laikraščių korespondentai norèjo su juo pasikalbèti. Taip pat jis sakè, kad Tautų Sąjungoje jam ne kartą buvo užsiminta, kad geriausia būtų, jei Lietuva ir Lenkija tiesiogiai susitartų. A. Voldemaro nuomone, Lietuvos delegacijos nuvažiavimas ị Varšuvą pakenkè jo darbui Ženevoje, nes praktiškai sustabdè derybas ir „iš viešumos jas perkèlè i slaptumą “136. Jis teigè, kad vykstant deryboms Ženevoje apie Lietuvos ir Lenkijos konfliktą girdejo visas pasaulis, o apie derybas Varšuvoje nerašè net Lenkijos laikraščiai. Interviu pabaigoje A. Voldemaras informavo, kad Tautų Sąjunga per ji Lietuvos Vyriausybei ịteikẻ notą, kurioje buvo rašoma, kad rytinèje Lietuvos dalyje, o kartu ir Vilniaus srityje reikès daryti plebiscitą, ir klausè, ar Lietuvos Vyriausybė sutinka su šiuo pasiūlymu. Tokia pat nota nusiųsta ir Lenkijai informuojant, kad L. Żeligowskio kariuomenè turès išeiti iš Vilniaus srities. A. Voldemaras aiškino, kad dabar Tautų Sąjunga lauks abiejų šalių atsakymo. Be to, jis saké, kad Tautų Sąjunga i tas teritorijas, kuriose planuojamas plebiscitas, siunčia specialią komisiją,

${ }^{133} 19201216$ P. Klimo telegrama J. Purickiui. LCVA, f. 383, ap. 7, b. 92, 1. 16.

${ }^{134}$ Klimas, P. Iš mano atsiminimu, p. 287.

${ }^{135} 19201220$ P. Klimo telegrama J. Purickiui. LCVA, f. 383, ap. 7, b. 92, 1. 5. ${ }^{136}$ Tautų Sajunga ir mūsų klausimas. Interviu su A. Voldemaru, grịžusiu iš TS posèdžio Ženevoje. Lietuva. 192101 09, Nr. 6, p. 2. 
jai vadovauti paskyrė generolą Alfredą Burtą. Žurnalistams paklausus, ar Ženevoje A. Voldemaras nebandè asmeniškai kalbètis su I. Paderewskiu ar S. Aszkenazy, jis atsakè, kad santykiai buvo tik oficialūs, nes tartis, kai jau sulaužyta sutartis ir pažadai, jis nematė galimybès. A. Voldemaras aiškino, kad atmetus plebiscito pasiūlymą jokios Tautų Sąjungos sankcijos Lietuvai negresia, jam ne kartą buvo pasakyta, kad už tai gali būti tik moralinè atsakomybè.

Savo straipsniuose A. Voldemaras kaltino delegacijos pirmininką dr. Joną Staugaitị ígaliojimų peržengimu, siūlant lenkams autonomiją Lietuvoje ir „sutvarkymą Lietuvos kantonais“137. A. Smetona rašè, kad 1920 m. rudeni, kai A. Voldemaras Ženevoje derèjosi su Lenkijos atstovais dèl Vilniaus ir pareiškè, jog Lietuva jokiu būdu neatsisakys savo sostinès, Kaune atsirado „lenkų piršlių“, kurie pasiūlè nutraukti derybas Ženevoje ir pasiųsti delegaciją i Varšuvą pusiau oficialių derybų be Tautų Sąungos tarpininkavimo ${ }^{138}$. Tam sumanymui pritarẻ Kontrolès komisijos pirmininkas pulkininkas P. Chardigny, todèl Lietuvos Vyriausybè sutiko. Oficialiai buvo rašoma, kad delegacija vyksta aptarti plebiscito vykdymo klausimų. A. Smetonos teigimu, lengvatikė Lietuvos valdžia, siųsdama delegaciją, sudarytą iš Seimo narių ir nepartinių visuomenès atstovų, padarẻ klaidą, nes po šių derybų buvo pasiūlytas Hymanso projektas.

$1921 \mathrm{~m}$. vasario 4 d. 60-ajame posėdyje užsienio reikalų ministras J. Purickis Seimui pranešè, kad Paryžiuje susirinkusi Antantės ministrų pirmininkų konferencija $1921 \mathrm{~m}$. sausio $26 \mathrm{~d}$. nutarè pripažinti de jure Estiją ir Latviją, tačiau Lietuvos pripažinimą atidèjo dèl neišspręsto rytų-pietų sienos klausimo ${ }^{139}$. Socialdemokratas V. Čepinskis kalbejo, kad Lietuvos atstovai užsienyje, o ypač delegacija Paryžiuje,

${ }^{137}$ Prof. A. Voldemaras. Lenkai ir mes. Laisvè. 192101 14, Nr. 10, p. 1; Prof. A. Voldemaras. Lenkija ir mes. Laisve. 192101 18, Nr. 13, p. 1-2.

${ }^{138}$ A. Sm. [Antanas Smetona]. Senoji byla ir „naujoji stadija“. Lietuviu balsas. $19211108-09$, Nr. 3, p. 1.

${ }^{139} 19210204$ I sesijos 60 posèdis. Steigiamojo Seimo darbai, Kaunas, 1920-1922. 
visada iš aukšto žiūrèjo ị Latviją ir Estiją. Jis pasiūlè vykdyti tikslingesnę ir gudresnę politiką. V. Čepinskis aiškino, kad Lietuva nepripažinta dèl to, jog kliudo sudaryti barjerą prieš Sovietų Rusiją, nes čia yra likęs Prancūzijos ir Anglijos kapitalas. Jis kaltino Lietuvos atstovą Tautų Sąjungoje A. Voldemarą, kad nieko nebuvo daroma, norint sustiprinti Lietuvos tarptautinę padetį.

$1921 \mathrm{~m}$. sausio 21 d. A. Voldemaras atsisakè delegacijos Tautų Sąjungoje vadovo pareigų, vasarị ji pakeitè E. Galvanauskas ${ }^{140}$. Apie A. Voldemaro pakeitimą P. Klimas atsiminimuose rašè:

„Kilo abejojimų dèl mūsų atstovo rungtynėse. Voldemaras buvo didele intelektuali jèga. Bet jis vis dar mums buvo lyg „homo novus“, lyg per daug abstraktus mąstytojas, dialektikas. Be to, jis atitrūko nuo visuomenès, jo grupei nepatekus ị Steigiamąji Seimą. Jis nebebuvo nè valdžioje. Reikejjo ieškoti atsakingesnio atstovo, bent Vyriausybès tarpe." ${ }^{\text {141 }}$

Kaip matome, pagrindinè nepasitikejjimo priežastis buvo ta, kad A. Voldemaras nebuvo nei Seime, nei Vyriausybeje.

1920 m. A. Voldemaras parengė ir išleido 2 leidinius apie Lietuvos ir Lenkijos bendrą istoriją ir santykius: Berlyne išleido 38 puslapių brošiūrą „Lietuva ir Lenkija“, o Paryžiuje išspausdino traktatą „RusųLenkų-Lietuvių santykiai“, kurị sudarė 2 dalys: „Rusų-Lenkų-Lietuvių santykiai“ ir „Demarkacijos linijos ir jų martirologija“.

Brošiūroje "Lietuva ir Lenkija“ jis analizavo bendrą Lietuvos ir Lenkijos istoriją: valstybių padalijimų priežastis, atkūrimo programas ir perspektyvas ${ }^{142}$. Prof. A. Voldemaras rašè, kad visos Lenkijos politinès partijos nori kurti Lenkiją su 1772 metų sienomis, tačiau tuo metu buvo bendra Lietuvos ir Lenkijos valstybè. Lenkija, ignoruodama istorinius faktus, norejo be sutikimo prisijungti Lietuvą. Jis

${ }^{140}$ Bukaitè, Vilma. Nepriklausomybès Akto signataras Petras Klimas, p. 178.

${ }^{141}$ Klimas, P. Iš mano atsiminimu, p. 293.

${ }^{142}$ Profesorius A. Voldemaras, Lietuvos užsienio reikalų ministras. Lietuva ir Lenkija. Profesorius Augustinas Voldemaras. Raštai, p. 195-224. 
kritikavo lenkų politinio mesianizmo ir buvusios demokratijos mitus, pateikdamas istorinių faktų, paneigiančių tariamą mesianizmą ir aukštą demokratijos lygị. Jis rašè apie tai, kad lenkai ir sulenkèję Lietuvos aristokratai nesuprato lietuvių tautinio judejimo, kovojo su lietuvių kalba, nes tai buvo grèsmė jų svajonei atkurti Lenkiją, sujungtą su Lietuva. A. Voldemaras prognozavo, kad prie Lenkijos prijungtos nelenkiškos provincijos bus blogai administruojamos, nes nepakaks išsilavinusių žmonių, vyraus ekonominio ir intelektinio gyvenimo stagnacija, skurdas, o iš daugelio tautų sudaryta Lenkija taps vidaus kovų arena. Jo nuomone, tokia Lenkija būtų nauja, blogesnè buvusios Rusijos laida $^{143}$. Ši brošiūra buvo dalijama Europos valstybių diplomatams, kad jie geriau susipažintų su Lietuvos siekiais ir suprastų jos santykius su Lenkija.

Antrame leidinyje, kurị sudarė dvi dalys „Rusų-Lenkų-Lietuvių santykiai“ ir „Demarkacijos linijos ir jų martirologija“, jis paneigè Lenkijos kaltinimus Lietuvai dèl bendrų lietuvių ir sovietų kariuomenių veiksmų, pateikè faktų apie tai, kad Lenkijos kariuomenė nuolat pažeidžia demarkacijos linijas. Šie leidiniai buvo dalijami užsienio diplomatams siekiant supažindinti su Lietuvos pozicija ir kèlé nerimą Lenkijos diplomatams ${ }^{144}$.

Atliktas tyrimas rodo, kad A. Voldemaro negalima kaltinti, jog jis be Vyriausybès žinios priemė plebiscito pasiūlymą, nes galutinị sprendimą prièmé užsienio reikalų ministras J. Purickis. Lietuvos delegacijai labai pakenkè nenuosekli Lietuvos Vyriausybės užsienio politika. Užsienio reikalų ministras neatsižvelgè ị delegacijos narių patarimus, pasidavė Tautų Sąjungos Kontrolès komisijos spaudimui ir tuo labai apsunkino delegacijos Ženevoje veiklą. A. Voldemaras tai pat ne visur buvo teisus. Jis buvo viešų pareiškimų ir notų šalininkas ir neịvertino neformalių pokalbių su užsienio šalių diplomatais

${ }^{143}$ Profesorius A. Voldemaras, Lietuvos užsienio reikalų ministras. Lietuva ir Lenkija. Profesorius Augustinas Voldemaras, p. 223-224.

${ }^{144}$ Vilkelis, G. Lietuvos ir Lenkijos santykiai Tautu Sajungoje, p. 83. 
svarbos. Lietuva, atsikūrusi po daugiau kaip 120 metų okupacijos ir aneksijos, turèjo spręsti sunkius užsienio politikos klausimus, tačiau neturèjo valstybės veikejjų, turinčių didelę diplomatinę patirtị ir mokančių spręsti tokias problemas. Jaunai Lietuvos diplomatijai reikejjo ìveikti agresyvią labiau patyrusių kaimyninių šalių, turinčių savų interesų Lietuvos atžvilgiu, propagandą. Siekiant atremti jų argumentus, reikejjo gerai išmanyti Lietuvos ir tų šalių istoriją, todèl tam labai tiko prof. A. Voldemaras. Negausi Lietuvos inteligentija, kurdama valstybę, kartu mokèsi jai atstovauti ir ginti jos interesus, todèl negalèjo išvengti klaidų.

\section{Hymanso projektų kritika}

$1921 \mathrm{~m}$. kovo 3 d. Tautų Sąjunga panaikino sprendimą rengti plebiscitą ir vietoj jo pasiūle tiesiogines derybas, kurioms tarpininkautų Tautų Sąjungos atstovas ${ }^{145}$. Lietuvos ir Lenkijos derybos prasidejo $1921 \mathrm{~m}$. balandžio 20 d. Briuselyje, joms tarpininkavo Belgijos atstovas prie Tautų Sąjungos P. Hymansas. Dar prieš atvažiuojant delegacijoms ị Briuselị Lenkijai ir Lietuvai buvo žinoma, kad Tautų Sąjunga siūlys konfederacijos projektą. $1921 \mathrm{~m}$. gegužès $11 \mathrm{~d}$. per derybas Briuselyje, kurioms tarpininkavo P. Hymansas, Lietuvai ir Lenkijai buvo pasiūlytas projektas, pagal kurị Lietuva turèjo tapti federacine valstybe, sudaryta iš lygiateisių Vilniaus ir Kauno kantonų, lenkų ir lietuvių kalbos turejjo būti pripažintos valstybinèmis kalbomis. Užsienio politika, karo ir ekonomikos reikalai ateityje turèjo būti reguliuojami per politinị organą, išrinktą Lietuvos ir Lenkijos Seimų.

A. Voldemaras labai daug dèmesio skyrè Briuselio deryboms, kritikuodamas ir nurodydamas Vyriausybès ir delegacijos daromas klaidas. $1921 \mathrm{~m}$. balandžio $20 \mathrm{~d}$. delegacijai išvykus ị Briuselị, straipsnyje „Mazgas virsta kilpa“ jis kaltino Lietuvos Vyriausybę nuolaidu-

${ }^{145}$ Tautų Sajungos nusprendimas dèl plebiscito Vilniuj. Lietuva. 192103 06, Nr. 51, p. 2. 
mu dèl to, kad kovo 3 d. prièmè Paryžiaus pasiūlymą tiekti maistą okupuotam Vilniaus kraštui ir maitinti L. Żeligowskio kariuomenę $e^{146}$. Jo nuomone, Lenkija neprièmė tos dovanos todèl, kad norejjo pririšti Lietuvą tvirtais juridiniais ryšiais ir, jeigu Lietuvos valdžia toliau bus tokia nuolaidi, „užtrauks ant Lietuvos kaklo kilpą“. Balandžio 23 d. A. Voldemaras sukritikavo Seimo posėdyje paskelbtą užsienio reikalų ministro J. Purickio parengtą derybų su Lenkija Briuselyje programą. Aptardamas kiekvieną programos punktą, jis stebėjosi neaiškia ministro kalba ir abejojo, ar jis išmano tarptautinę teisę, tačiau labiausiai A. Voldemarą sujaudino autonomijos pažadejjimas Rytų Lietuvai. Jis rašè, jei valdžia tikrai taip mano, ką sako J. Purickis, tai Lietuva neturi valdžios, o jei valdžia vieną sako, o kitą daro, tai ji ne Lietuvos valdžia $^{147}$.

Balandžio $28 \mathrm{~d}$. straipsnyje „Užmirštieji Briuselio derybose klausimai“ A. Voldemaras siūlè Lietuvos delegacijai remtis ne Suvalkų, bet Maskvos sutartimi, nes Sovietų Rusija išsižadejo savo teisių i išvardintas sutartyje žemes, todèl jos teisètai priklauso Lietuvai. Lenkų argumentas, kad tai padarè nepripažinta bolševikų valdžia, neturi jokio juridinio pagrindo, nes ir jiems Sovietų valdžia yra teisèta - tai rodo Rygos sutarties pasirašymas ${ }^{148}$.

A. Voldemaras kritikavo Seimą, kad siunčia savo narius ị derybas užsienyje ir taip kišasi į Vyriausybės funkcijas. Jo manymu, šitaip nuimama atsakomybè nuo Vyriausybès pečių ${ }^{149}$.

Nutrūkus deryboms Briuselyje $1921 \mathrm{~m}$. birželio pradžioje dauguma Lietuvos delegacijos narių grịžo ị Lietuvą. Birželio 13 d. Seimo

${ }^{146}$ Voldemaras, A. Mazgas virsta kilpa. Lietuvos balsas. 192104 20, Nr. 2, p. 2.

${ }^{147}$ Voldemaras, A. Aklumas ar apgaudinejjimas. Lietuvos balsas. 192104 23, Nr. 3, p. 2.

${ }^{148}$ Prof. A. Voldemaras. Užmirštieji Briuselio derybose klausimai. Lietuvos balsas. 192104 28, Nr. 4, p. 2.

${ }^{149}$ Prof. A. Voldemaras. Seimo metinès sukaktuvès. Lietuvos balsas. 192105 19, Nr. 12, p. 1. 
Užsienio reikalų komisijos pirmininkas ir delegacijos narys M. Sleževičius karių klube kalbejjo apie derybų eigą ${ }^{150}$. Susitikime M. Sleževičius priminè, kad prieš metus Spa konferencijoje „lenkai išsižadèjo Vilniaus“. Kalbèdamas apie derybas, jis ilgokai aiškinosi, kodèl Lietuvos delegacija pradejo svarstyti ekonominius ir karinius klausimus, bet ne sienos klausimą. Jis pripažino, kad delegacija, susisiekusi su Kaunu, prièmė P. Hymanso pasiūlymą kaip tolesnių derybų pagrindą. Jo aiškinimu, sèkmė yra ta, kad Vilnius bus pripažintas Lietuvai ir kad buvo paneigti lenkų melagingi tvirtinimai apie Vilniaus lenkiškumą. Delegacijos dalyvio pasakojimą auditorija sutiko gana šaltai, todèl paskaitos pabaigoje M. Sleževičius pradejjo kaltinti Lietuvos dvarininkus neprincipingumu, o buvusį Lietuvos atstovą Londone grafą A. Tiškevičių pavadino „federacijos šalininku“. Rašydamas apie M. Sleževičiaus paskaitą, A. Voldemaras paneigè jo tvirtinimą, kad Spa konferencijoje „lenkai atsižadèjo Vilniaus“, stebèjosi, kodèl valdžia Lietuvoje neparengè „plataus memorialo deryboms“, M. Sleževičiaus kaltinimus Lietuvos dvarininkams jis pavadino demagogija, o kaltinimus grafui A. Tiškevičiui - netiesa ${ }^{151}$.

Birželio $19 \mathrm{~d}$. naktị buvo pasikèsinta ị užsienio reikalų ministrą J. Purickį. Pistoletu buvo šauta pro ministro miegamojo langą. Kulka pataikè ị sieną ties miegančio J. Purickio krūtine. Nusikaltèlis pabėgo per sodą, o lauke buvo rasta popieriaus skiautè su nupiešta kaukole ${ }^{152}$. Policija pradejo tyrimą, traktuodama pasikèsinimą kaip politinį nusikaltimą. Visuomenèje sklandė ir gandai, kad pasikèsinimą organizavo nuo valdžios nustumtas A. Voldemaras, tačiau tokiems gandams nebuvo pagrindo, nes A. Voldemaro „priešiškumas“ pasireikšdavo užsienio politikos kritika laikraščio puslapiuose ir susirinkimuose ${ }^{153}$.

${ }^{150}$ Voldemaras, A. P. Sleževičiaus pranešimas apie Briuselio derybas. Lietuvos balsas. 192106 18, Nr. 24, p. 1.

${ }^{151}$ Ten pat.

${ }^{152}$ Norèjo nušauti Užs. Reik. Ministerị. Lietuvos balsas. 192106 21, Nr. 25, p. 2.

${ }^{153}$ Gaigalaitė, A.; Žeimantienè, J. Juozas Purickis-Vygandas. Vilnius, 2004, p. 48. 
Lietuvoje kilę protestai prieš Hymanso projektą tęsėsi visą vasarą. Tautos pažangos partijos lyderiai važinėjo po Lietuvą ir kūrẻ Žemdirbių sąjungos skyrius. Liepos 17 d. Vilkaviškyje vykusiame Suvalkijos žemdirbių suvažiavime dalyvavę A. Smetona ir A. Voldemaras nušvietė Lietuvos užsienio politiką, smarkiai kritikavo Vyriausybès ir Seimo darbą. Suvažiavime Seimo nariai Jonas Valaitis ir Jonas Krikščiūnas bandè ginti Seimą, tačiau nesugebejo diskutuoti su Tautos pažangos partijos lyderiais ${ }^{154}$. Suvažiavimas prièmé pareiškimą, kuriame Lietuvos valdžia kaltinama sulaužiusi Lietuvos Konstituciją, o Steigiamasis Seimas - nesugebejjimu organizuoti valstybès darbo, todèl žemdirbiai siūlè paleisti Steigiamąji Seimą ir daryti naujus rinkimus. Nors žemdirbių susirinkimuose priimamos rezoliucijos pasižymėjo smarkia Vyriausybės ir Seimo kritika, tačiau šiuose susirinkimuose dalyvaudavo keli šimtai žmonių, todèl didelio vaidmens antihymansinejje kampanijoje nevaidino.

Rugsėjo pradžioje P. Hymansas paskelbè antrąji projektą, kuris jau buvo palankesnis Lietuvai, nes buvo derintas su Lietuvos atstovu Anglijoje T. Naruševičiumi, tačiau projektas buvo pateiktas ne kaip diskusijų pagrindas, bet kaip galutinis susitarimas, kurị reikèjo priimti ${ }^{155}$. Pagal antrąji projektą, Vilniaus kraštui suteikiama autonomija, tačiau Vilnius būtų buvusi Lietuvos sostinè ir jame turejo reziduoti Lietuvos valdžia.

1921 m. rugsėjo 9 d. 121-ajame Steigiamojo Seimo posėdyje Lietuvos socialdemokratų partijos (toliau - LSDP) frakcija įteike interpeliaciją Ministrui Pirmininkui ir užsienio reikalų ministrui dèl derybų su Lenkija. Joje Hymanso projektas vertinamas kaip bandymas inkorporuoti Lietuvą ị Lenkijos sudèti, smerkiamas Lietuvos delegacijos nuolaidumas ir noras priimti projektą, primenamas Vyriausybès pažadas nesiųsti delegacijos ir klausiama, ką Vyriausybė mano daryti, kad nebūtų pasirašyta ši Lietuvai katastrofiška sutartis ${ }^{156}$.

${ }^{154}$ Žemdirbių suvažiavimas. Lietuvos balsas. 192107 19-20, Nr. 37, p. 2.

${ }^{155}$ Žepkaitè, R. Diplomatija imperializmo tarnyboje. Vilnius: Mokslas, 1980, p. 152.

${ }^{156}$ 1921-09-09 I sesijos 121 posèdis. Steigiamojo Seimo darbai, Kaunas, 1920-1922. 
A. Voldemaras savo straipsniuose gyrẻ LSDP frakciją už interpeliaciją ir teigé, kad ši interpeliacija paskatino priimti Lietuvą i Tautų Sąjungą, nes Tautų Sąjunga nenorèjo, kad būtų nuverstas Ministrų kabinetas. Jis kaltino užsienio reikalų ministrą J. Purickị, kad šis vienus nurodymus duoda delegacijai, o visai ką kita šneka Seime ${ }^{157}$. A. Voldemaras ir A. Smetona ne kartą kritikavo Vyriausybę ir Seimą dèl neaiškios ir neryžtingos užsienio politikos, kaip išeitị iš susidariusios padèties siūlè atsistatydinti Vyriausybei, patarè atšaukti delegaciją, ragino Seimą pareikšti nepasitikèjimą Vyriausybe, kaltino valdančiąją koaliciją bailumu, apgaudinėjimu, atsakomybès vengimu ${ }^{158}$.

Socialdemokratų interpeliacija, Lietuvos visuomenès nepasitenkinimas ir Tautų Sąjungos baimè, kad Hymanso projektas nebus priimtas, prisidejo prie to, kad $1921 \mathrm{~m}$. rugsẻjo $22 \mathrm{~d}$. posėdyje Lietuva buvo priimta ị Tautų Sąjungą, nors daugelis valstybių dar jos nebuvo pripažinusios de jure. Prieš balsavo Lenkija, taip dar kartą pademonstruodama savo neigiamą požiūrị ị Lietuvą, ir jos sąjungininkẻ Rumunija. ${ }^{159}$

Rugsèjo pabaigoje A. Voldemaras rašè, kad Tautos pažangos partija nesuinteresuota nuversti Ministrų kabineto, tačiau Seimo nepasitikejimas jam leistų atsisakyti Hymanso projekto. Jis kritikavo Seimą, kad jam pasmerkus Hymanso projektą delegacijos pirmininkas E. Galvanauskas Tautų Sąjungos Tarybai tvirtina, jog Lietuva sutinka priimti Hymanso projektą. Jis aiškino, kad J. Purickis vienas instrukcijas duoda delegacijai, o visai priešingai kalba Seime. A. Voldemaras nurodé, kad i Tautų Sąungą buvo planuojama priimti Latviją ir Estiją, o Lietuvos prièmimą atidèti, tačiau socialdemokratų

${ }^{157}$ Voldemaras, A. Šviesos kibirkštis. Lietuvos balsas. 192109 15-16, Nr. 61, p. 2; Voldemaras, A. Seimas ir Hymanso projektas. Lietuvos balsas. 192109 27-28, Nr. 66, p. 1.

${ }^{158}$ Voldemaras, A. Padetis be išeities. Lietuvos balsas. 192107 05-06, Nr. 31, p. 1; Prof. A. Voldemaras. Kodèl tyli? Lietuvos balsas. 192110 8-9, Nr. 71, p. 1; A. Sm. [Smetona, A.]. Kodèl ir kam? Lietuviu balsas. 192111 24-25, Nr. 10, p. 1; Voldemaras, A. Lydint d-rą Purickį. Lietuviu balsas. 192112 15-16, Nr. 19, p. 2.

${ }^{159}$ P. Klimo pranešimas apie derybas. Lietuvos balsas. 1921-10-5-6, Nr. 70, p. 3. 
interpeliacija paskatino Tautų Sąjungos Tarybą pakeisti nuomonę ir priimti Lietuvą i šią organizaciją ${ }^{160}$. Kritikuodamas Lietuvos delegacijos Ženevoje taktiką, jis rèmėsi užsienio spauda ir Tautų Sąjungos leidiniais, todèl jo kritika buvo paremta konkrečiais faktais ir rimtais argumentais. Jis lygino J. Purickio ir E. Galvanausko kalbas Lietuvos Seime su kalbomis Tautų Sąjungoje ${ }^{161}$.

Kituose straipsniuose A. Voldemaras dèstè, kad Vyriausybės oficiozas „Lietuva“ ir krikščionių demokratų laikraštis „Laisvë“, publikuodami palankius straipsnius apie Tautų Sąjungą ir informaciją iš Lenkijos spaudos, kad lenkai nepatenkinti Hymanso projektu, ruošia dirvą projektui priimti, o valdžia, vaikiškai pasitikėdama savimi, veda valstybę pražūtin ${ }^{162}$. Jis teigè: „Pirmutinis reikalingas politikui gabumas - tai numatyti iš anksto, kas ir kaip. Paskui mokèti suprasti savo ir svetimas klaidas ir sugebèti atitaisyti savąsias, gi svetimąsias sunaudoti." "163

A. Voldemaras neabejojo, kad dauguma Lietuvos gyventojų nori nepriklausomos Lietuvos, ir apgailestavo, kad jie leido save klaidinti ir apgaudinėti. A. Voldemaras citavo ištraukas iš delegacijos pirmininko E. Galvanausko Tautų Sąjungoje pasakytų kalbų, kuriose jis agitavo už galimą Lietuvos ir Lenkijos federaciją, ir priekaištavo Seimui, kad jo nesudraudè. Taip pat jis kaltino Lietuvos delegaciją, kad ji neprieštaravo, kai Lenkijos atstovas S. Aszkenazy kalbėdamas iškraipè Lietuvos istorijos faktus.

Nesèkmingos derybos dèl Hymanso projektų, informacijos slèpimas nuo visuomenès smarkiai pakenkè Vyriausybės autoritetui. Be

${ }^{160}$ Voldemaras, A. Seimas ir Hymanso projektas. Lietuvos balsas. 1921-09-27-28, Nr. 66, p. 1.

${ }^{161}$ Voldemaras, A. Du posėdžiu. Lietuvos balsas. 1921-09-29-30, Nr. 67, p. 1.

${ }^{162}$ Voldemaras, A. Ruošia dirvą. Lietuvos balsas. 1921-10-4-5, Nr. 69, p. 1; Voldemaras, A. Lietuvos ir Lenkijos konfederacija. Lietuvos balsas. 1921-10-6-7, Nr. 70, p. 2.

${ }^{163}$ Voldemaras, A. Lietuvos ir Lenkijos konfederacija. Lietuvos balsas. 1921-10-6-7, Nr. 70, p. 2. 
to, gruodžio pradžioje kilo skandalas dèl spekuliacijos Lietuvos pasiuntinybėse Vokietijoje ir Sovietų Rusijoje, dẻl jo iš užsienio reikalų ministro pareigų teko atsistatydinti J. Purickiui. Gruodžio 12 d. J. Purickis atsistatydino iš šių pareigų dèl išaiškejjusių spekuliacijos Lietuvos pasiuntinybėse Maskvoje ir Berlyne faktų, nors atleistas buvo nuo 1922 m. sausio 1 dienos. Laikinai užsienio reikalų ministro pareigas perèmé viceministras P. Klimas. A. Voldemaras apibūdino J. Purickio vadovavimo stilių kaip sistemą, kurios pagrindiniai bruožai buvo faktų slëpimas, apgaudinejjimas, atsakomybès vengimas, stengimasis visiems įtikti ir nieko aiškiai nepasakyti, kad prireikus būtų galima kitaip aiškinti savo žodžius ${ }^{164}$.

1921 m. gruodžio 22 d. 156-ajame Steigiamojo Seimo posèdyje P. Klimas padarè pranešimą apie Lietuvos ir Lenkijos santykių eigą nuo 1919 metų iki pastarųjų ịvykių. Po pranešimo vienbalsiai buvo pritarta Vyriausybès nutarimui nepriimti Hymanso projekto, bet pasilikti Tautų Sąungoje ${ }^{165}$. A. Voldemaras, rašydamas apie ši Seimo posèdị, pareiškè, kad Seimas, nepasmerkęs delegacijos ir Ministrų kabineto veiksmų, pritare Hymanso projekto principams, tik nesutiko su jo redakcija ${ }^{166}$.

A. Voldemaras, atidžiai ir įtariai sekęs Vyriausybès ir Seimo laikyseną bendraujant su Lenkija, Tautos pažangos partijos laikraštyje pateikè Šveicarijos profesoriaus Makso Nydermano nuomonę, pareikštą gruodžio 17 d. laikraštyje „Neue Schweizer Zeitunge“167. M. Nydermanas teigè, kad Lietuvos valdžia iki paskutinès minutès pritarè Hymanso projektui, bet spaudžiama socialistų ir Tautos pažangos partijos turejo ji atmesti. Jis pareišké, kad socialistai nori Lietuvą atitraukti nuo Vakarų ir pasukti ị Sovietų Rusiją, o Tautos pa-

${ }^{164}$ Voldemaras, A. Lydint d-rą Purickį. Lietuviu balsas. 1921-12-15-16, Nr. 19, p. 2. ${ }^{165} 1921-12-22$ I sesijos 156 posėdis. Steigiamojo Seimo darbai. Kaunas, 1920-1922. ${ }^{166}$ Voldemaras, A. Kas atmesta iš Hymanso projekto. Tautos balsas. 1921-12-27-28, Nr. 2, p. 1.

${ }^{167}$ Prof. A. Voldemaras. Ko galime laukti iš TS pirmojo posèdžio? Tévynés balsas. Nr. 1, 1922-01-11, p. 1. 
žangos partija, pralaimèjusi rinkimus, negali nurimti, todèl pradejo akciją, norèdama supriešinti Vyriausybę ir Seimą. Straipsnio pabaigoje A. Voldemaras pranašavo, kad Hymanso projektas lyg kokia šmėkla persekios K. Griniaus Ministrų kabinetą iki jo paskutinių dienų ir dar ilgai kliudys naujajam Ministrų kabinetui.

A. Voldemaras, apibendrindamas lietuvių ir lenkų ginčą Tautų Sąjungoje, rašè, kad sumaniai nagrinėjant bylą Tautų Sąjungoje Lietuvai galèjo būti labai naudinga. Jis kritikavo, kad Vyriausybè neturèjo jokios politikos dèl santykių su Lenkija, todèl, perduodama Tautų Sąjungai bylą, nepasirūpino ją tiksliai apibrèžti, siuntè ị Tautų Sąjungą gausias delegacijas, nepasiruošusias deryboms. Klaida jis pavadino ir paskutinès delegacijos prašymą perkelti bylą i Tarptautinị Hagos teismą ${ }^{168}$.

A. Voldemaras, kritikuodamas Lietuvos Vyriausybès ir diplomatų taktiką, daug kur buvo teisus. P. Hymansas sugebejo Lietuvos delegacijai primesti nepalankią derybų taktiką, kai neišsprendus esminio sienų klausimo buvo pradètos svarstyti konvencijos su Lenkija. Delegacijos pirmininkas E. Galvanauskas galbūt pernelyg pasitikèjo savo, kaip derybininko, sugebejimais ir neatsižvelgè i kitų delegacijos narių, Lietuvos Seimo ir visuomenès daugumos nuomonę. Užsienio reikalų ministras J. Purickis laviruodamas slèpé informaciją nuo Seimo ir visuomenès, savo oficialiuose pranešimuose pateikdamas ne visus Lietuvos pasiūlymus, kai iš tikrųjų instrukcijose Lietuvos nuolaidos siekiant atgauti Vilniaus kraštą buvo gerokai didesnès ${ }^{169}$. Lietuva šiose derybose parode didelị nuolaidumą, siekdama savo tikslo, tačiau tokioms nuolaidoms nepritarè dauguma Lietuvos gyventojų, todèl kažin ar jos būtų buvusios realizuotos.

Pasitraukęs iš Lietuvos delegacijos Tautų Sąjungoje pirmininko pareigų A. Voldemaras atidžiai sekè Vyriausybės žingsnius užsienio

${ }^{168}$ Voldemaras, A. Lietuvių-lenkų ginčo TS pabaiga. Te்vynès balsas. 1922-01-24-25, Nr. 7, p. 1.

${ }^{169}$ Plačiau: Veilentienè, A. Lietuvos visuomenès požiūris ì Hymanso projektus ir pasikèsinimas į Ernestą Galvanauską. Istorija. 2016, t. 104, Nr. 4, p. 56-85. 
politikos srityje ir dažnai kritikuodavo pasirinktą taktiką. Vyriausybè ị kritiką reaguodavo skausmingai ir, pasinaudodama karo padèties ìstatymais, uždarydavo Tautos pažangos partijos laikraščius, tačiau šie po kurio laiko išeidavo kitais pavadinimais. Lietuvai atmetus antrąji Hymanso projektą, Tautos pažangos partijos lyderiai kritišką dèmesị sutelkè ị vidaus politiką.

\section{Išvados}

1. A. Voldemaras, laikinai eidamas užsienio reikalų ministro pareigas, prisidejo prie paskutinès instrukcijos Lietuvos delegacijai Maskvoje rengimo, ragino nepasitikèti Sovietų Rusija ir spausti ją kuo greičiau ratifikuoti sutartị.

2. Būdamas Lietuvos atstovas Tautų Sąjungoje A. Voldemaras neprieštaravo plebiscito pasiūlymui, bet jo neprièmé. Galutinị sprendimą prièmè užsienio reikalų ministras J. Purickis, vèliau kaltę už tai suvertęs A. Voldemarui.

3. Vyriausybė nepaklausė A. Voldemaro. Pasirašiusi paliaubas su L. Żeligowskiu ir pasiuntusi delegaciją i Varšuvą, ji pakenkẻ Lietuvos delegacijos darbui Ženevoje.

4. A. Voldemaras aktyviai gynė Lietuvos interesus Tautų Sąjungoje, savo viešose kalbose, notose ir leidiniuose paneigdamas neteisingus Lenkijos atstovų kaltinimus ir istorijos iškraipymus. Jis buvo viešos diplomatinès veiklos šalininkas ir neịvertino neoficialios komunikacijos su Tautų Sąjungos pareigūnais ir šalių diplomatais reikšmès.

5. Vyriausybės nepasitikèjimą A. Voldemaru lèmè ne tiek instrukcijų nesilaikymas, kiek jo savarankiškumas ir priklausymas opozicijoje atsidūrusiai Tautos pažangos partijai.

6. Kritikuodamas Vyriausybès poziciją dèl Hymanso projektų, A. Voldemaras buvo teisus. Vyriausybė žaidė dvigubą žaidimą, pritardama Tautų Sąjungos siūlymams ir kartu ramindama visuomenę, 
kad Hymanso projektų ji nepriims, nors dauguma Lietuvos piliečių nepritarè konfederaciniams ryšiams su Lenkija.

7. Nors Tautos pažangos partija nepateko ił Steigiamąji Seimą, A. Voldemaras Steigiamojo Seimo laikotarpiu daré didelę ịtaką Lietuvos užsienio politikai ne tik laikinai eidamas užsienio reikalu ministro pareigas ir dirbdamas Tautų Sąjungoje, bet ir vèliau savo publicistiniais straipsniais formuodamas viešąją nuomonę užsienio politikos klausimais.

\title{
THE POSITION OF AUGUSTINAS VOLDEMARAS IN THE FOREIGN POLICY DURING THE OPERATION OF THE CONSTITUENT SEIMAS
}

\author{
Audroné VeilentienĖ
}

\section{Summary}

Keywords: Augustinas Voldemaras; foreign policy; Constituent Seimas; United Nations.

The paper analyses the position of prof. Augustinas Voldemaras on the foreign policy issues during the period of the Constituent Seimas. Then, until the formation of Kazys Grinius' Cabinet of Ministers, prof. A. Voldemaras temporarily took the position of the Minister of Foreign Affairs and was representative of Lithuania in the United Nations. Being in opposition he strictly criticized the foreign policy of Cristian Democrats.

As Minister of Foreign Affairs, A. Voldemaras took an active part in working out the instructions for the Lithuanian delegation in Moscow and was in favor of the secret attachment to the agreement as well as of defense of Lithuanian interests even by using military measures. Following the withdrawal from the duty of the Foreign Affairs Minister, in his publicist articles, Voldemaras offered numerous advice on how the Lithuanian government should behave in the face of the war between Poland and Soviet Russia and warned not to trust Russia and explained what was to be done after the recovery of Vilnius and also urged to keep in mind the issue of Klaipeda region.

Being the delegate of Lithuania to the United Nations he defended Lithuania's interests in the case of Poland and Lithuania and was unreasonably blamed for violation of the Constitution and adopting the idea of plebiscite. The archive docu- 
ments show that due to the communication problems with the Lithuanian Foreign Ministry, A. Voldemaras did not object to the idea of the plebiscite and even succeded in the request of the 10 days term until the Government's reply. The final decision was made by Foreign Minister J. Purickis who thought that in declining the suggestion, Lithuania may fail to get support from England and the Antante. Because of the disagreement in tactics between A. Voldemaras and J. Purickis, the former withdrew from the position of the delegate.

A. Voldemaras paid great attention to the further development of the case of Lith- uania and Poland in the United Nations. In his articles he put forward the ideas on the tactics and criticized the Government by claiming that it did not pursue any definite policy concerning the relations with Poland, therefore, in passing the case to the $\mathrm{UN}$, it even failed to define the situation exactly, in addition, numerous, but totally unprepared delegations were sent to the UN. A. Voldemaras took the position that more clever actions in this case could have been more fruitful.

Even being in opposition, prof. A. Voldemaras made a great contribution and influence in forming the Lithuanian foreign policy.

Iteikta 2018 m. spalio $22 \mathrm{~d}$. 